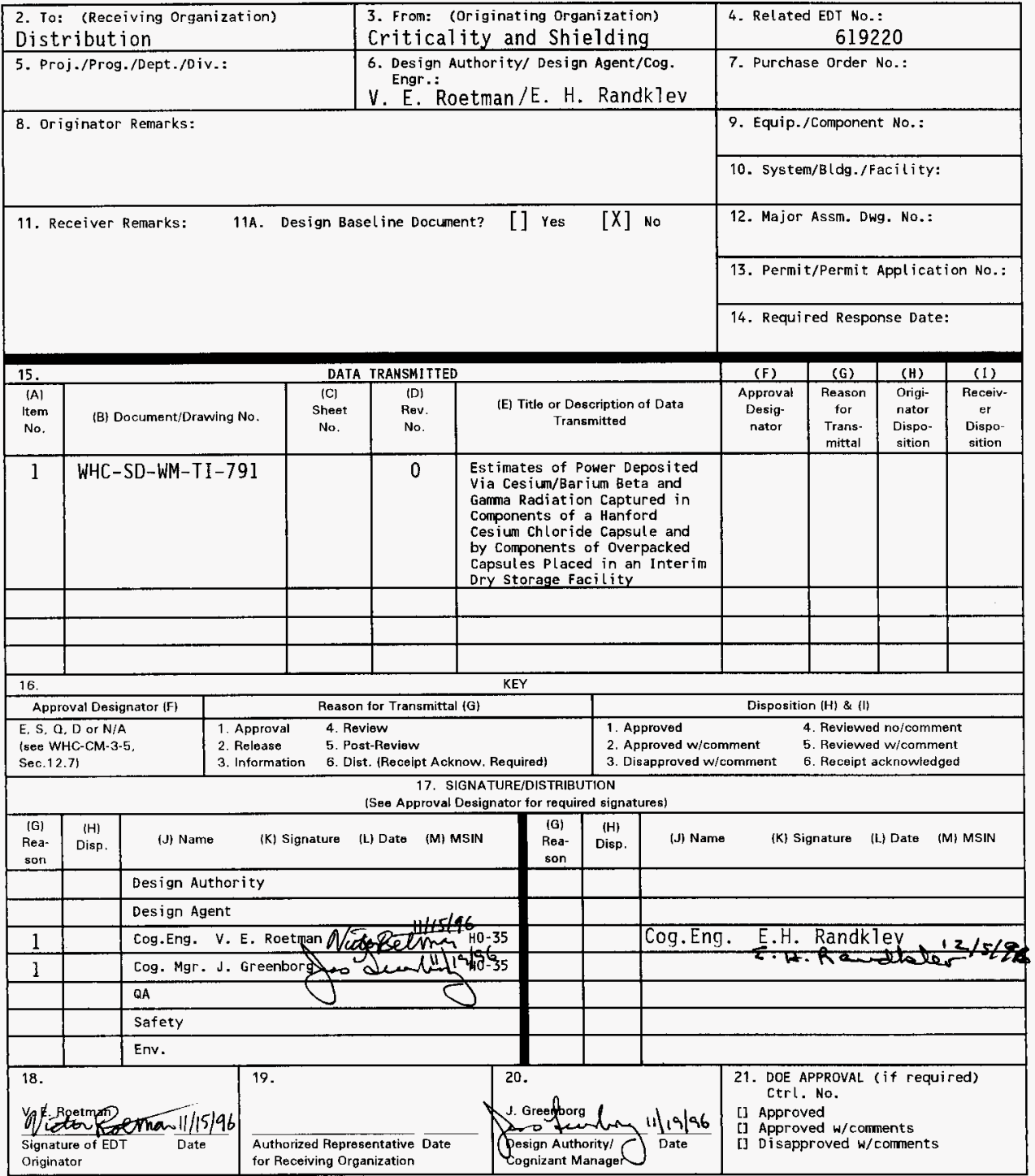




\section{Estimates of Power Deposited Via Cesium/Barium Beta and Gamma Radiation Captured in Components of a Hanford Cesium Chloride Capsule and by Components of Overpacked Capsules Placed in an Interim Dry Storage Facility}

V. E. Roetman/E. H. Randklev

Fluor Daniel Northwest Inc., Richland, WA 99352

U.S. Department of Energy Contract DE-AC06-96RL13200
EDT/ECN: $\quad 619220$
UC: 507
Org Code: 403
B\&R Code: EW3130010
Charge Code: D5222
Total Pages: $2843 \mathrm{kN}$

Key Words: Cesium Chloride Capsule, Power Deposition, Canister Storage

Abstract: This documents the Power Deposition Calculations for the Cesium Chloride Capsules and Overpacked Capsules.

TRADEMARK DISCLAIMER. Reference herein to any specific comercial product, process, or service by trade name, trademark, manufacturer, or otherwise, does not necessarily constitute or imply its endorsement, recommendation, or favoring by the United States Government or any agency thereof or its contractors or subcontractors.

Printed in the United States of America. To obtain copies of this document, contact: WHC/BCS Document Control Services, P.0. Box 1970, Mailstop H6-08, Richland WA 99352, Phone (509) 372-2420; Fax (509) 376-4989.
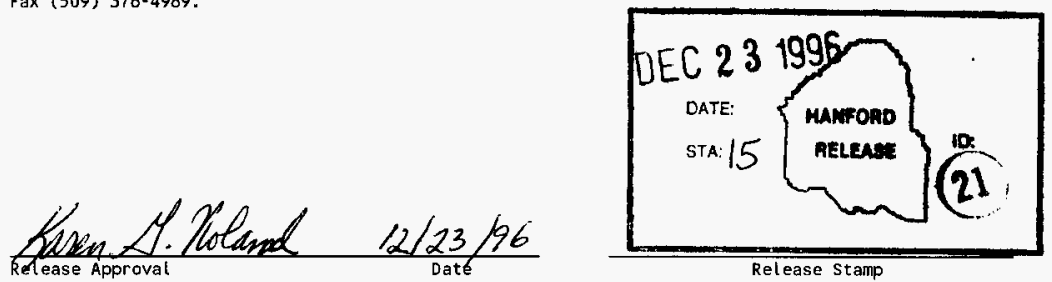

Approved for Public Release 


\section{WHC-SD-WM-TI-791 REV 0}

\section{TABLE OF CONTENTS}

1.0 INTRODUCTION .................................. 4

2.0 SUMMARY ......................... 5

3.0 MODEL FOR A SINGLE CESIUM CHLORIDE CAPSULE . . . . . . . . . 5

4.0 RESPECTIVE MODELS FOR AN OVERPACK CONTAINING EIGHT HANFORD CESIUM CHLORIDE CAPSULES AND FOR A CSB STORAGE TUBE CONTAINING OVERPACKED

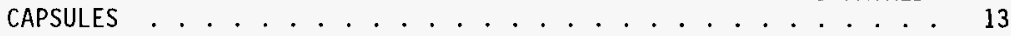

5.0 MODEL FOR INFINITE ARRAY OF CSB STORAGE TUBES LOADED WITH OVERPACKED

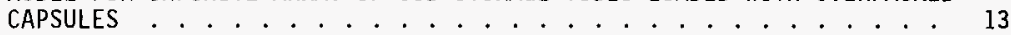

6.0 CESIUM SOURCE . . . . . . . . . . . . . . . . 15

7.0 PREDICTIONS OF DEPOSITION IN OTHER COMPONENTS . . . . . . . 16

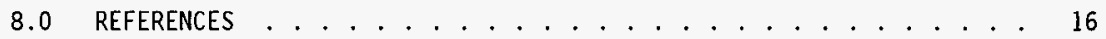
APPENDIX I MCNP INPUT FILES ......................... 18 APPENDIX II COPIES OF GUIDANCE LETTERS AND MEMORANDUMS . . . . . . . . 21 


\section{LIST OF FIGURES}

Figure 1. Configuration for tube-in-tube overpack concept . . . . . . . 14

Figure 2. Specific Power Deposition in a Single CsCl Capsule in Air . . . 7

Figure 3. Axial cross-section of the model for eight cesium chloride capsules in an overpack loaded in a storage tube in a Canister Storage Building (CSB) ............. 8

Figure 4. Specific Power Deposition across a CSCl Capsule Loaded Overpack in one CSB Storage Tube Results are in Watts/gram* for 1 Curie of Cs137 in each capsule . . . . . . . . . . . . 9

Figure 5. Specific Power Deposition across a CsCl Capsule in a Loaded Overpack Results are in Watts/gram* for 1 Curie of $\mathrm{Cs}-137$ in each capsule. . . . . . . . . . . . . 10

Figure 6. Specific Power Deposition across a CsCl Capsule Loaded Overpack in a CSB Storage Tube for an Infinite Array of such CSB Tubes. Results are in Watts/gram* for 1 Curie of Cs-137 in each capsulell

Figure 7. Specific Power Deposition across a CsC1 Capsule in a Loaded Overpack in a CSB Interim Storage Tube for an Infinite Array of such CSB Tubes. Results are in Watts/gram* for 1 Curie of Cs-137 in each capsule . . . . . . . . . . . . . 12 


$$
\text { WHC-SD-WM-TI-791 REV } 0
$$

\section{LIST OF TABLES}

Tab7e 1. Inner Capsule Dimensions . . . . . . . . . . 6

Table 2. Outer Capsule Dimensions . . . . . . . . . . . 6

Table 3. Capsule Overpack Dimensions . . . . . . . . . . . . . 13

Table 4. ${ }^{137} \mathrm{Cs} /{ }^{137 m} \mathrm{Ba}$ Gamma Distribution ............ 15 
WHC-SD-WM-TI-791 REV 0

ESTIMATES OF POWER DEPOSITED VIA CESIUM/BARIUM BETA AND GAMMA RADIATION CAPTURED IN COMPONENTS OF A HANFORD CESIUM CHLORIDE CAPSULE AND BY COMPONENTS OF OVERPACKED CAPSULES PLACED IN AN INTERIM DRY STORAGE FACILITY

\subsection{INTRODUCTION}

The deposition of power in Hanford cesium chloride capsules and in the components of design concepts for overpacking and interim storage were determined as requested (Randklev, 1996a). The power deposition results from the selective capture of gamma and beta radiation coming from the decay of the ${ }^{137} \mathrm{Cs}$ isotope in the $\mathrm{CsCl}$ contained in the capsules. The following three cases were analyzed: a) a single $\mathrm{CsCl}$ capsule, b) an overpack containing eight CsCl capsules, and c) an infinite square array of such overpacks as placed in tubes of a interim dry storage facility. The power deposition was expressed as watts per gram for each of the respective physical design components in these three cases. Per the analyses request and guidance (Randklev 1996a), the primary analysis objective was to characterize, for each case, the power deposition across the radial cross-section at the expected axial position of maximum deposition. As requested, this primary part of the analysis work was done using choices for component dimension and material properties that would reasonably characterize the maximum deposition profile across the salt (CsCl) and the inner capsule barrier of the double walled metal capsule system used to construct the Hanford capsules. The secondary objective was to further evaluate the deposition behavior relative to the influence of axial position. The guidance (Randklev 1996a) also requested an analysis case that involved a lag-storage pit in a hot-cell, in which a cylindrical metal basket from a transportation cask would be used to position several capsules in the lagstorage pit. Although the basic model for the lag storage concept evaluation was essentially completed by the end of $F Y-96$, the analys is was not run because of the need to prioritize and limit the work scope due to funding limitations for FY-97.

The specific purpose for performing the subject set of analyses (Randklev 1996a) is to obtain power deposition values (i.e., per the decay of $\left.{ }^{137} \mathrm{Cs}\right)$ that can then be used as input into an analysis of the heat transfer (i.e., component temperature) response (Randklev 1996d) for such cases. The overall objective is to support the TWRS program evaluations of capsule disposal options, which could be implemented if, and when the DOE changes their current designation as "by-product" material, to "waste" material. It was found that the Hanford reference literature concerning the capsules does contain a few reports on previous Monte Carlo code determinations of the power deposition values for assemblages involving the Hanford CsCl capsules. However, in one case (Campbe11, 1981) the results are now believed to be seriously in error, and the other two reported analyses (Sasmor, et a1, 1988; Midgett, 1995) involve capsule + other components in assemblages that differed significantly from the subject concepts addressed in this present analysis. 
The Monte Carlo N-Particle (MCNP) transport code (Breismeister, 1993 and Carter, 1995) was used to model, in three dimensions, a single capsule; eight capsules plus an overpack and a CSB tube. For these respective models, the MCNP code was then run to calculate the predicted power density deposition for the decay of ${ }^{137} \mathrm{Cs}$. For simplicity of applying the results to specific capsules, the model assumed that only one curie of ${ }^{137} \mathrm{Cs}$ was in the salt column of each capsule as modeled.

\subsection{SUMMARY}

The power density deposition values predicted by the MCNP code for the given conceptual model are reported in Figures 2 through 7 . Since the MCNP calculations were run on the basis of assuming an inventory of one curie of ${ }^{137} \mathrm{Cs}$ per capsule, the deposition values appropriate for a given Hanford $\mathrm{CsCl}$ capsule is obtained by just multiplying these MCNP predicted deposition values by the estimated number of curies of ${ }^{137} \mathrm{Cs}$ for the subject capsule.

\subsection{MODEL FOR A SINGLE CESIUM CHLORIDE CAPSULE}

The Randklev 1996a and 1996b references provided most of the information needed regarding capsule materials, dimensions, etc., needed for setting up the model. Each of these Hanford $\mathrm{CsCl}$ capsules is composed of two independent encapsulation barriers, one located inside the other, where the inner capsule contains the $\mathrm{CsCl}$ salt. For the Hanford CsCl capsules, both the inner and outer capsule units are made of 316 stainless steel, which for this analysis was assumed to have a density of $7.9 \mathrm{~g} / \mathrm{cc}$. Per the guidance on analys is conservatism (Randklev 1996a) regarding the upper bound for such power deposition, it was assumed that the $\mathrm{CsCl}$ had a density of $3.8 \mathrm{~g} / \mathrm{cC}$ (Randklev 1996c). All the air gaps and void spaces were modeled as void (vacuum). Tables 1 and 2 list the dimensions of the inner and outer capsule components, respectively. For the model, the inner and outer capsules are assumed to share the same axial centerline, and are hence radially symmetrical. The inner and outer capsule were assumed to be co-centered axially, and the CsCl salt column was modeled as being in full contact with one end of the inner capsule (i.e., bottom end as melt-filled during fabrication) with a void space between the salt column and the other end of the inner capsule. As modeled, this is a very simplified representation of the void space distribution, since in an actual $\mathrm{CsCl}$ inner capsule the $\mathrm{CsCl}$ contains cooling cracks, a shrinkage void generally distributed at the top of the salt column and along the axial centerline region of the upper third or so of the salt column. 
Table 1. Inner Capsule Dimensions

\begin{tabular}{|l|l|l|}
\hline Outer Diameter: & 2.255 & inches \\
\hline Wall Thickness: & 0.136 & inches \\
\hline Inner Diameter: & 1.983 & inches \\
\hline Overal1 Length: & 19.725 & inches \\
\hline $\begin{array}{l}\text { Cap Thickness: } \\
\text { Inner Cavity }\end{array}$ & 0.400 & inches \\
\hline Dength: & 18.925 & inches \\
\hline Mass ity of CsCl: & 3.8 & $\mathrm{~g} / \mathrm{cc}$ \\
\hline
\end{tabular}

Table 2. Outer Capsule Dimensions

\begin{tabular}{|l|l|l|}
\hline Outer Diameter: & 2.657 & inches \\
\hline Wa11 Thickness: & 0.136 & inches \\
\hline Inner Diameter: & 2.385 & inches \\
\hline Overa11 Length: & 20.775 & inches \\
\hline Cap Thickness: & 0.400 & inches \\
\hline $\begin{array}{l}\text { Inner Cavity } \\
\text { Length: }\end{array}$ & 19.975 & inches \\
\hline
\end{tabular}

The MCNP input file for a single capsule is provided in Attachment $I$. 
Figure 2.

Specific Power Deposition in a Single CsCl Capsule in Air Results are in Watts/gram* for 1 Curie of Cs-137

*Gamma and beta power in Watts deposited per gram of material in the specified region.

The figure is an axial cross-section of the capsule model. All results are radially symmetrical across the capsule. The reported $\mathrm{CsCl}$ source region deposition rates include

2.60E-09.

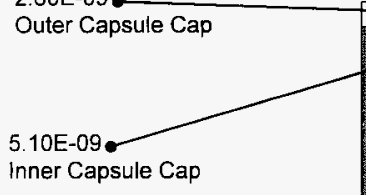

Inner Capsule Cap beta power deposited at 5.61E-07 Watts/gram.

Approximate void region for an actual capsule with interstitial void regions and nominal $\mathrm{CsCl}$ density.

$\rightarrow$ Void region as modeled for $2.7 \mathrm{~kg}$ of $\mathrm{CsCl}$ at $3.8 \mathrm{~g} / \mathrm{cc}$, for maximum power deposition.
7.87E-08

Outer Capsule Wall

(Axial average over

length of capsule)

1.30E-07

Inner Capsule Wall

(Axial average over

length of capsule)
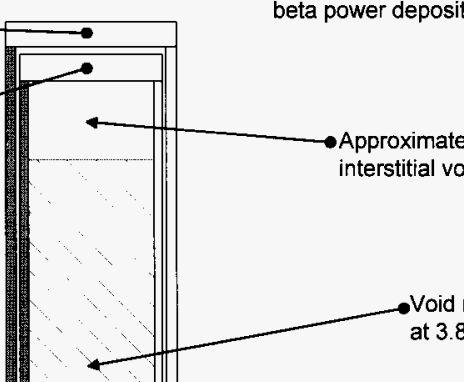
Figure 3.

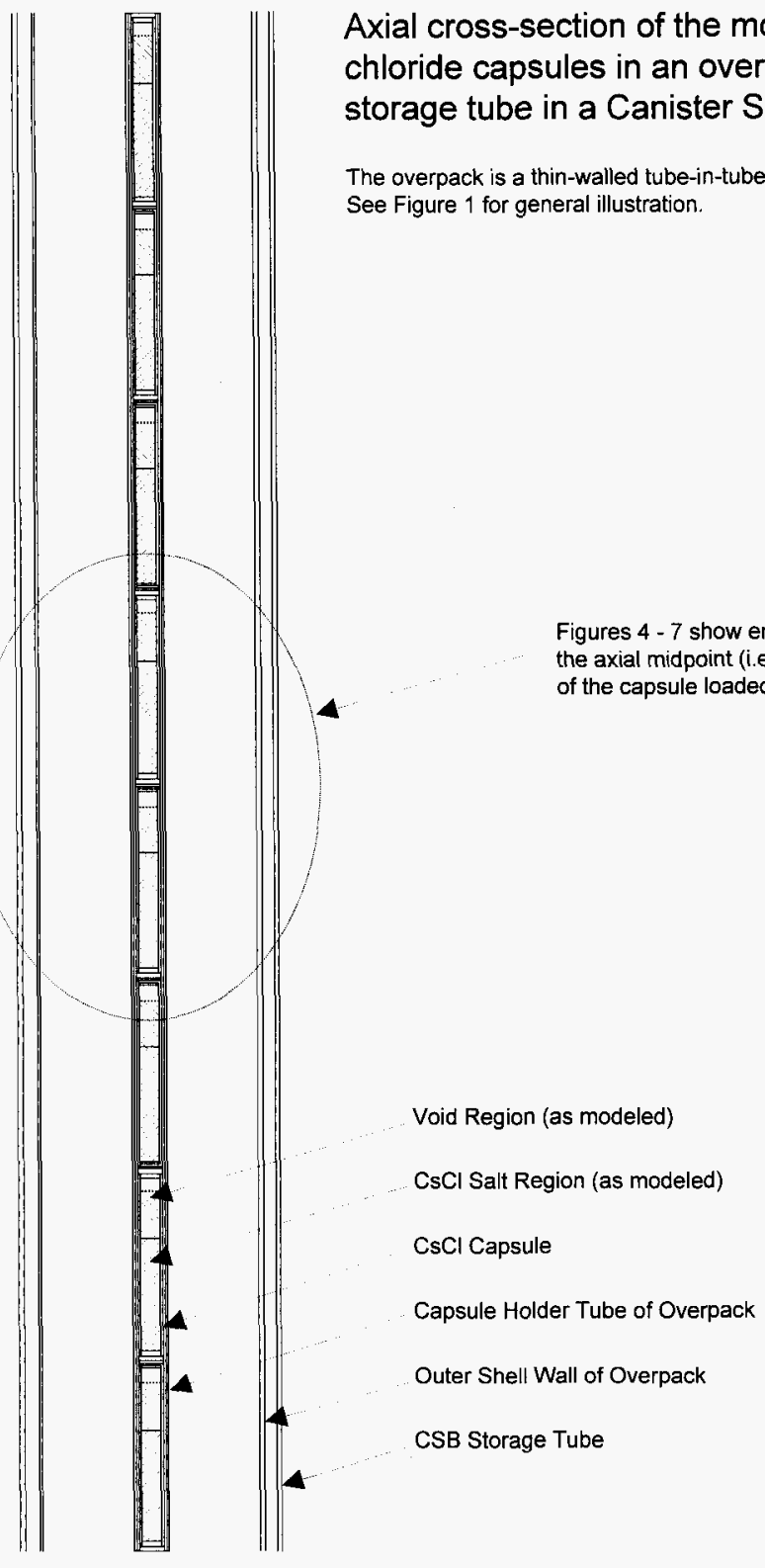


Figure 4.

Specific Power Deposition across a $\mathrm{CsCl}$ Capsule Loaded Overpack in one CSB Storage Tube

Results are in Watts/gram* for 1 Curie of Cs-137 in each capsule.

*Gamma and beta power deposited in Watts per gram of material in the specified region.

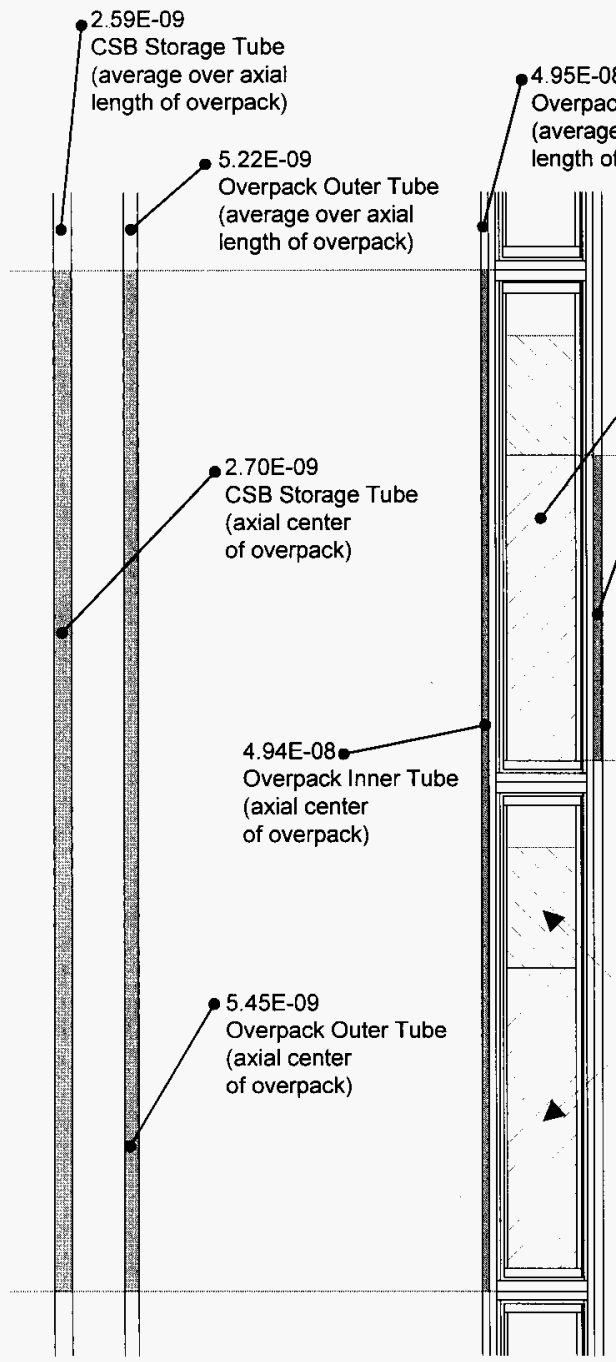

There are eight $\mathrm{CsCl}$ Capsules in each overpack. All results are radially symmetrical.

Reported $\mathrm{CsCl}$ source region deposition rates include beta power deposited at 5.61E-07 Watts/gram. 
Figure 5.

Specific Power Deposition across a CsCl Capsule in a Loaded Overpack Results are in Watts/gram* for 1 Curie of Cs-137 in each capsule.

Eight capsules per overpack.

All results are radially symmetrical across the capsule.

The reported $\mathrm{CsCl}$ Source region deposition rates include beta power deposited at 5.61E-07 Watts/gram.

*Gamma and beta power deposited in Watts per gram of material in the specified region.

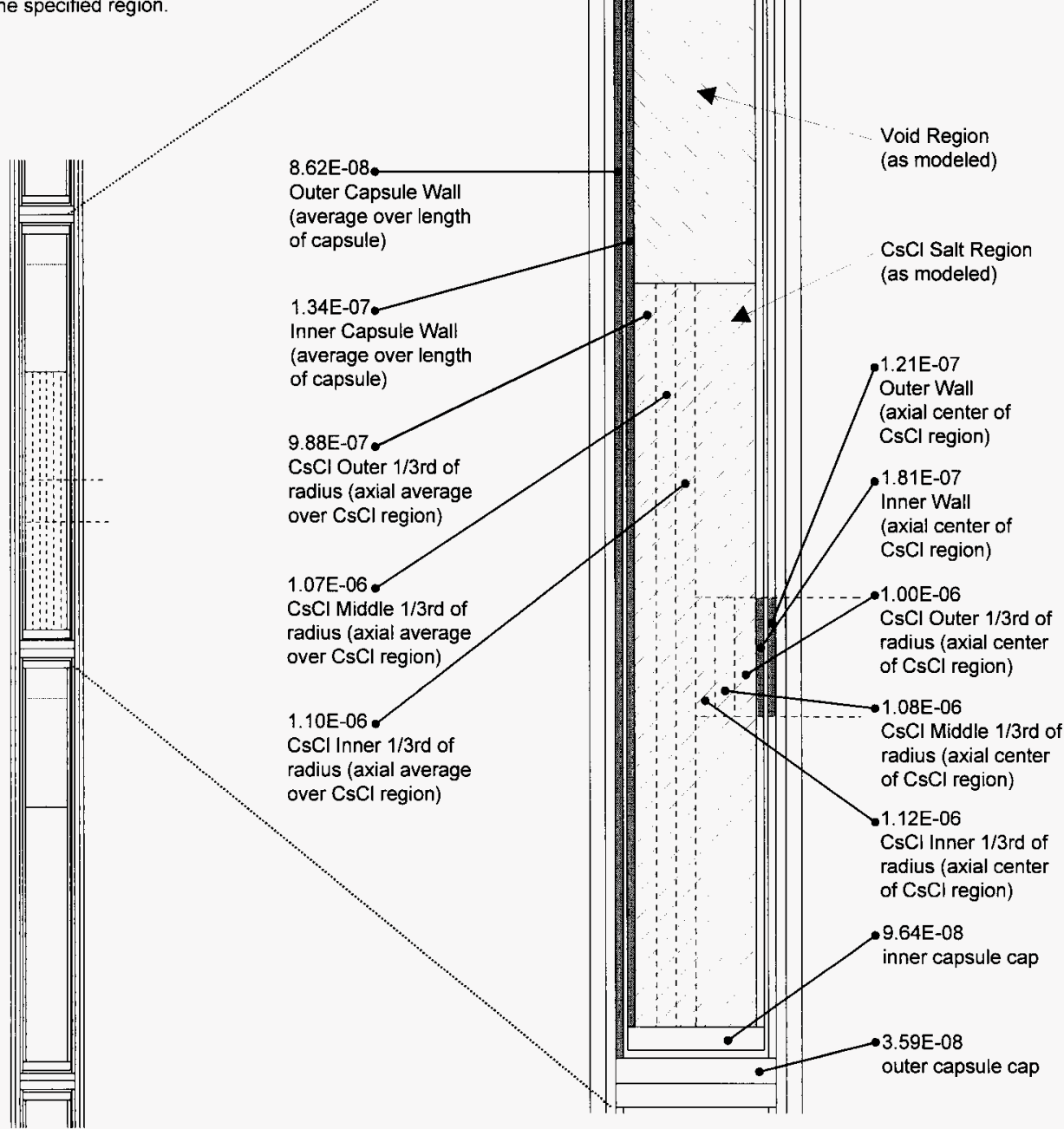


Figure 6.

Specific Power Deposition across a CsCl Capsule Loaded Overpack in a CSB Storage Tube for an Infinite Array of such CSB Tubes.

Results are in Watts/gram* for 1 Curie of Cs-137 in each capsule.

*Gamma and beta power deposited in Watts per gram of material in the specified region.

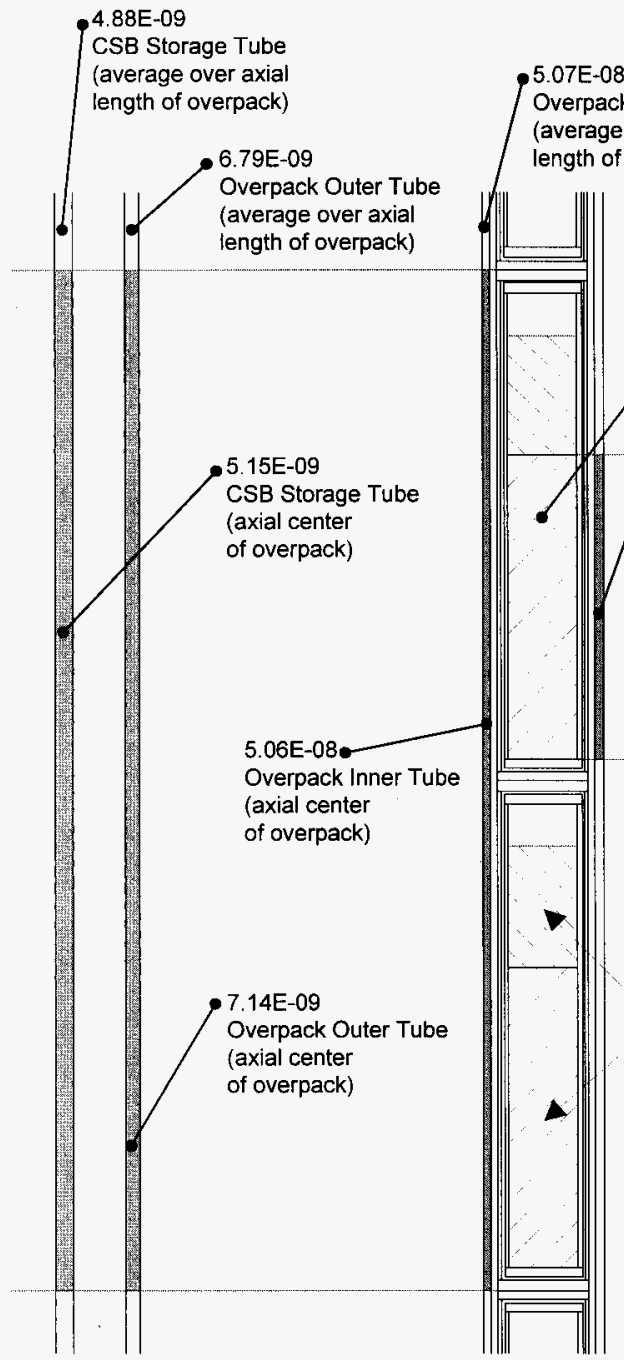

CSB Storage Tube

(average over axial

Overpack Outer Tube (average over axial length of overpack)

CSB Storage Tube

(axial center

of overpack)
There are eight $\mathrm{CsCl}$ Capsules in each overpack. All results are radially symmetrical.

Reported $\mathrm{CsCl}$ source region deposition rates include beta power deposited at 5.61E-07 Watts/gram.

Overpack Inner Tube

(average over axial

ngth of overpack)

1.03E-06

$\mathrm{CsCl}$ Source

(average over

salt column)

6.83E-08

Overpack Inner Tube (axial extent corresponds to source region of capsule)

7.33E-09

Overpack Outer Tube

(axial extent corresponds

to source region of capsule)

5.24E-09

CSB Storage Tube

(axial extent corresponds

to source region of capsule)

Void Region (as modeled)

$\mathrm{CsCl}$ Salt Region (as modeled)

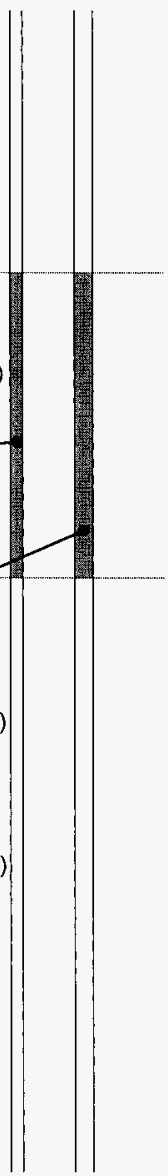


Figure 7.

Specific Power Deposition across a CsCl Capsule in a Loaded Overpack in a CSB Interim Storage Tube for an Infinite Array of such CSB Tubes. Results are in Watts/gram* for 1 Curie of Cs-137 in each capsule.

Eight capsules per overpack.

All results are radially symmetrical across the capsule. The reported $\mathrm{CsCl}$ Source region deposition rates include beta power deposited at 5.61E-07 Watts/gram.

${ }^{\star}$ Gamma and beta power deposited in Watts per gram of material in the specified region.

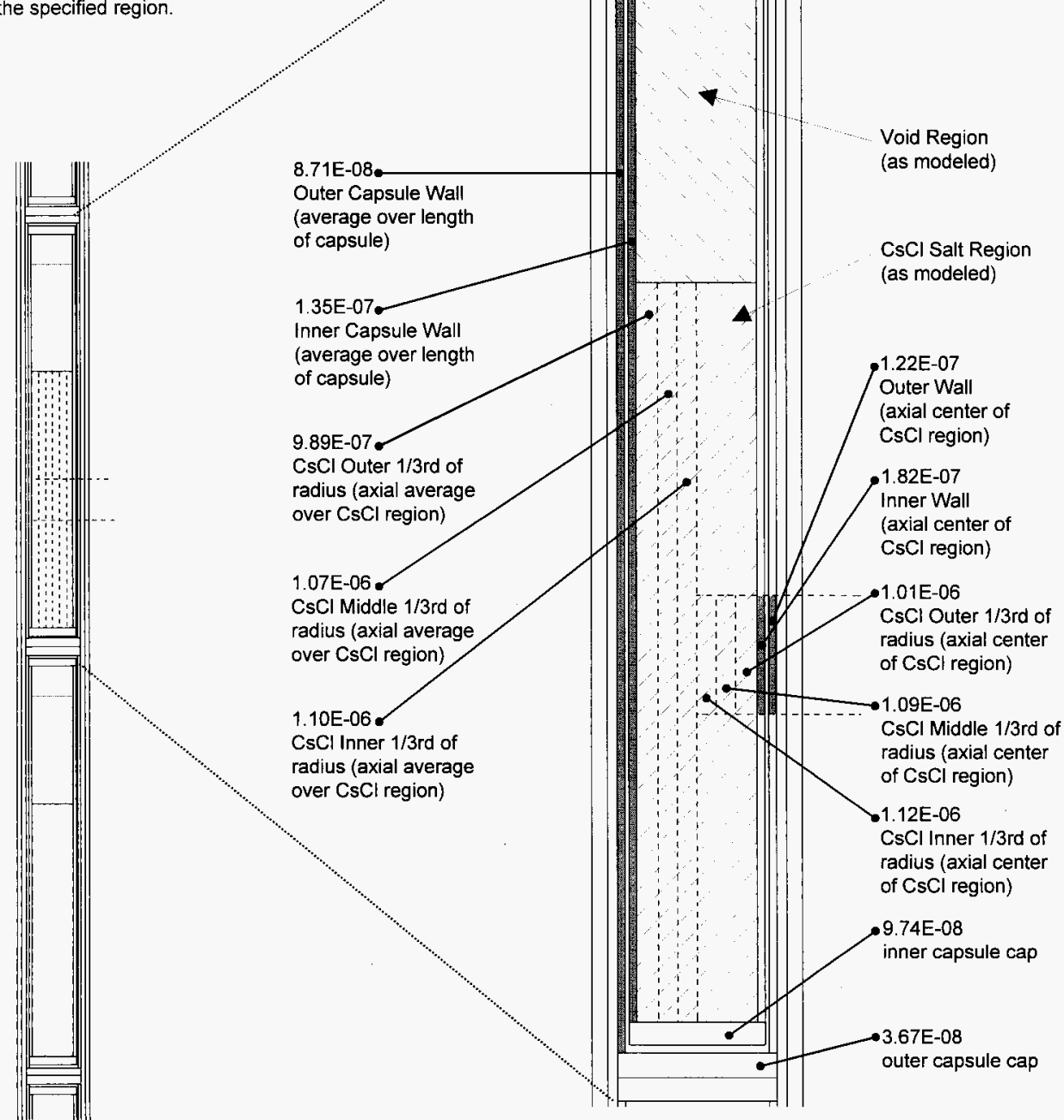


WHC-SD-WM-T1-791 REV 0

\subsection{RESPECTIVE MODELS FOR AN OVERPACK CONTAINING EIGHT HANFORD CESIUM CHLORIDE CAPSULES AND FOR A CSB STORAGE TUBE CONTAINING OVERPACKED CAPSULES}

The Randklev 1996a and 1996b references provided most of the information (i.e., design concept, component dimensions, materials, properties, etc.) needed to model this configuration of components. Figure l provides a general schematic illustration of the major components and their relative positioning for the design concept of a capsule overpack loaded with eight CsCl capsules. As the guidance notes, this overpack concept is one that is a candidate for use in the disposal option involving a federal geologic repository. Per this concept, the overpack was modeled as containing eight $\mathrm{CsCl}$ capsules with the eight capsules placed axially end-to-end along the axial centerline of the overpack. The capsules were assumed to be held in this position by a small diameter guide tube held in place by other fixturing (e.g., axially aligned fin plates attached perpendicular to the guide tube outer surface). The capsules were thus assumed to be radially co-centered within this guide tube, an outer tube, and then a CSB (Canister Storage Building) interim storage tube, which is a steel tube positioned in a vertical orientation within a CSB. The dimensions of the modeled overpack are listed in Table 3 . The inner and outer tubes were modeled as 316 stainless steel having the same density as was assumed in Section 3.0 for the single capsule model. The CSB tube was modeled as AISI/SAE-1020 carbon steel with an assumed density of $7.86 \mathrm{~g} / \mathrm{cc}$.

Table 3. Capsule Overpack Dimensions

\begin{tabular}{|l|l|l|}
\hline Guide Tube & 3 inches ID & $1 / 4$ inch thick \\
\hline Outer Case & 24 inches OD & $3 / 8$ inch thick \\
\hline CSB Tube & 28 inches OD & $\frac{1}{2}$ inch thick \\
\hline
\end{tabular}

The MCNP input file for the an eight capsule overpack is provided in Appendix I.

\subsection{MODEL FOR INFINITE ARRAY OF CSB STORAGE TUBES LOADED WITH OVERPACKED CAPSULES}

The MCNP model for the single CSB storage tube, as loaded with an overpack plus capsules, was modified by inserting four reflective surfaces to simulate a close packed infinite square array (i.e., a conservative case for power deposition) of such CSB tubes loaded with overpacked capsules. The specific spacing between the tube array assumed for this model is not that important to the results since the mean free path for the gamma radiation is about $6 \mathrm{~m}$ in air. For the capsules in overpacks in such a CSB array the power deposition profile across the radial cross-section of such a loaded CSB tube 


\section{WHC-SD-WM-TI-791 REV 0}

is $63 \%$ into the $\mathrm{CsCl}, 6.7 \%$ into the inner capsule wal1, 5.4\% into the outer capsule wa $11,7.1 \%$ into the guide tube holding the capsules in the overpack unit, $8.3 \%$ into the outer shell of the overpack unit, and $9.2 \%$ into the CSB tube wall. 
WHC-SD-WM-TI-791 REV 0

Figure 1.

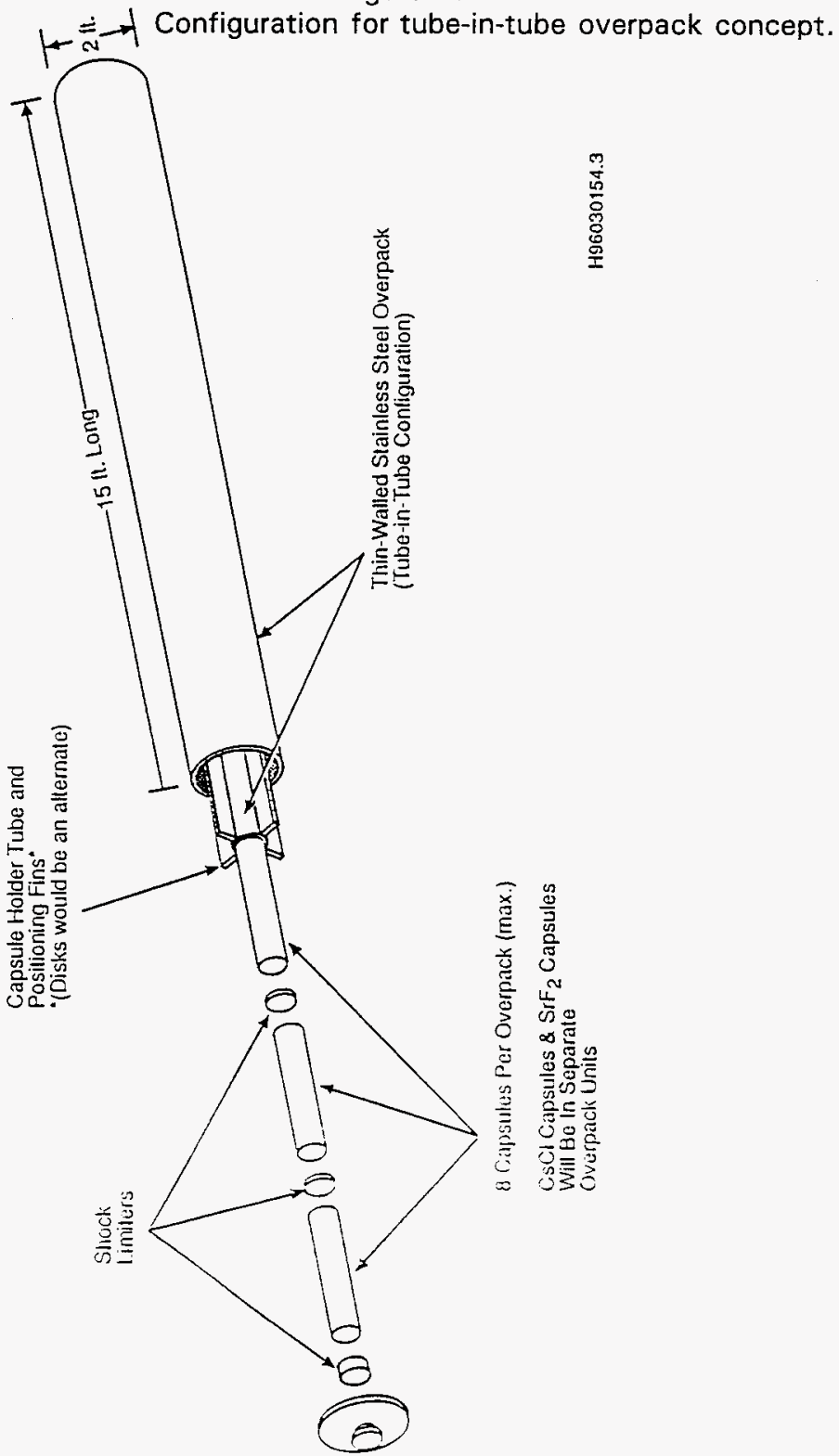




\subsection{CESIUM SOURCE}

The ISOSHLD code (Lourant 1990) was used to generate the gamma distribution for the decay of ${ }^{137} \mathrm{Cs}$ and the daughter product ${ }^{137 \mathrm{~m}} \mathrm{Ba}$, including the associated bremsstrahlung radiation in the $\mathrm{CsCl}$ source material. The gamma distribution is shown in Table 4. A photon strength of $3.626 \times 10^{10}$ photons per second for one curie of ${ }^{137} \mathrm{Cs}$ was used in the MCNP input file.

Table 4. ${ }^{137} \mathrm{Cs} /{ }^{137 \mathrm{~m}} \mathrm{Ba}$ Gamma Distribution

\begin{tabular}{|l|l|}
\hline Energy (MeV) & $\begin{array}{l}\text { Photons } / \mathrm{Sec} \\
\text { for } 37.65 \mathrm{kCj}\end{array}$ \\
\hline $1.500 \mathrm{E}-02$ & $3.182 \mathrm{E}+13$ \\
\hline $2.500 \mathrm{E}-02$ & $1.547 \mathrm{E}+13$ \\
\hline $3.500 \mathrm{E}-02$ & $1.042 \mathrm{E}+14$ \\
\hline $4.500 \mathrm{E}-02$ & $4.919 \mathrm{E}+12$ \\
\hline $5.500 \mathrm{E}-02$ & $3.708 \mathrm{E}+12$ \\
\hline $6.500 \mathrm{E}-02$ & $2.547 \mathrm{E}+12$ \\
\hline $7.500 \mathrm{E}-02$ & $1.990 \mathrm{E}+12$ \\
\hline $8.500 \mathrm{E}-02$ & $1.434 \mathrm{E}+12$ \\
\hline $9.500 \mathrm{E}-02$ & $1.096 \mathrm{E}+12$ \\
\hline $1.500 \mathrm{E}-01$ & $3.636 \mathrm{E}+12$ \\
\hline $2.500 \mathrm{E}-01$ & $7.220 \mathrm{E}+11$ \\
\hline $3.500 \mathrm{E}-01$ & $1.841 \mathrm{E}+11$ \\
\hline $4.750 \mathrm{E}-01$ & $7.770 \mathrm{E}+10$ \\
\hline $6.500 \mathrm{E}-01$ & $1.187 \mathrm{E}+15$ \\
\hline $8.250 \mathrm{E}-01$ & $2.689 \mathrm{E}+09$ \\
\hline $1.000 \mathrm{E}+00$ & $2.362 \mathrm{E}+08$ \\
\hline & \\
\hline
\end{tabular}

The total photon power predicted by the ISOSHLD code for the decay of 137cs was calculated to be $2.07 \times 10^{10} \mathrm{MeV} / \mathrm{s}$ for one $\mathrm{Ci}$ of ${ }^{137} \mathrm{Cs}$ in equilibrium with ${ }^{137 \mathrm{~m}} \mathrm{Ba}$. This equates to $3.31 \times 10^{-03}$ Watts. To estimate the amount of power deposited in the $\mathrm{CSCl}$ salt via beta radiation, a prediction was made for the total power released from ${ }^{137} \mathrm{Cs}$ decay (i.e., not just the contribution 
from photons). The total power predicted for the cesium/barium decay scheme using the ORIGEN2 code (Schmittroth 1994) was $4.82 \times 10^{-03}$ Watts. Thus the difference between these two predicted values (i.e., the ORIGEN2 value for total power released minus the ISOSHLD value for the total photon power released) is $1.51 \times 10^{-03}$ Watts. This difference is assumed to be the power absorbed in the $\mathrm{CsC} 7$ source region as beta radiation. For an estimate of 2.7 $\mathrm{kg}$ of $\mathrm{CsCl}$ per capsule (Randklev $1996 \mathrm{c}$ ), the beta deposition would be $5.61 \times 10^{-}$ ${ }^{07}$ Watts/g of $\mathrm{CsCl}$ for one $\mathrm{Ci}$ of ${ }^{137} \mathrm{Cs}$. This value was added to the MCNP gamma power density results for the $\mathrm{CsCl}$ source regions.

\subsection{PREDICTIONS OF DEPOSITION IN OTHER COMPONENTS}

The power density deposition values for the other components in each of the models (i.e., the components other than the CsCl salt column, such as the inner and outer capsule metal walls, tube walls for the overpack components, etc.) were then predicted using the MCNP code. A nominal capsule loading of $2.7 \mathrm{~kg}$ of $\mathrm{CsCl}$ per capsule was used in the analysis (Randklev, 1996C). Component dimensions and the $\mathrm{CsCl}$ density values were taken from the Randklev, $1996 \mathrm{~b}$ and 1996c references, respectively, and input into the MCNP code to obtain the power density values (Watts/g). The results of these calculations are reported in Figures 2 through 7 , and are expressed in units of Watts $/ \mathrm{g}$.

\subsection{REFERENCES}

Breismeister, J. F., Editor, 1993, MCNP--A General Monte Carlo Code N-Particle Transport Code, Version 4a, LA-12625, Los Alamos National Laboratory, Los Alamos, New Mexico, November 1993.

Campbe11, G. D., 1982, Strontium and Cesium Capsu7e Heat-Transfer Analysis, RHO-LD-167, Rev. 1, Rockwell Hanford Operations, Richland, Washington, September 1981 .

Carter, L. L., 1995, Certification of MCNP Version 4A for WHC Computer Platforms, WHC-P-SD-300001, Rev. 5, Westinghouse Hanford Company, Richland, Washington, May 1995.

Lourant, Israel $0 ., 1990$, Validation of ISOSHLD-PC on the IBM PC (PS-2/AT/XT), EDT-109878, WHC-SD-SQA-CSWD-303, Rev. 0, Westinghouse Hanford Company, Richland, Washington, February 1990.

Midgett, J. C., External Letter to J. E. Mecca (RL), Preliminary Analysis for Cesium and Strontium Capsule Storage at the Canister Storage Building, Letter No. 9502756b R5, Westinghouse Hanford Company, Richland Washington, September $21,1995$.

Randklev, E. H., 1996a, Request for Radiation Decay Energy Deposition Analyses to Support Thermal Analyses of Hanford Capsules Per Hanford Processing 
for Two Disposal Path Options Being Evaluated in a TWRS Decision Analyses. "Internal Letter 73510-96-028, to R. A. Schwarz, August 30, 1996, Westinghouse Hanford Company, Richland Washington. (See APPENDIX II for a copy.)

Randklev, E. H., 1996b, Informal memorandum to Victor E. Roetman, "Informal Notice of Analysis Priorities and Inputs, "September 17, 1996, Westinghouse Hanford Company, Richland, Washington. (See APPENDIX II for a copy.)

Randklev, E. H., 1996c, Informal memorandum to Victor E. Roetman, "EHR Selection of $\mathrm{CsCl}$ Density Value and Salt Wt./Caps."--- supporting MCNP modeling, September 26, 1996, Westinghouse Hanford Company, Richland, washington. (See APPENDIX II for a copy.)

Randklev, E. H., 1996d, Request for Thermal Analyses of Hanford Processing Per Two Disposal Path Options Being Evaluated in a TWRS Decision Analysis, Internal Letter 73510-96-030 to E. R. Cramer, September 30, 1996, Westinghouse Hanford Company, Richland, Washington. (See APPENDIX II for a copy.)

Sasmor, D. J., J. D. Pierce, G. L. Tingey, H. E. Kjarmo, J. Tills and D. C. McKeon, I988, Characterization of Two WESF Capsules After Five Years of Service, Sandia National Laboratories, Albuquerque, New Mexico, Apri1 1988.

Schmittroth, F. A., Conversion of ORIGEN2 to the Sun Workstations, WHC-SD-SWD-006, Rev. 1, Westinghouse Hanford Company, Richland, Washington, August 1994. 
WHC-SD-WM-TI-791 REV 0

\author{
APPENDIX I \\ MCNP INPUT FILES \\ Consisting of 11 pages, \\ including cover page.
}


WHC-SD-WM-II-791 REV 0

MCNP INPUT FILE FOR SINGLE CAPSULE WITH ONE CURIE OF ${ }^{137} \mathrm{Cs}$.

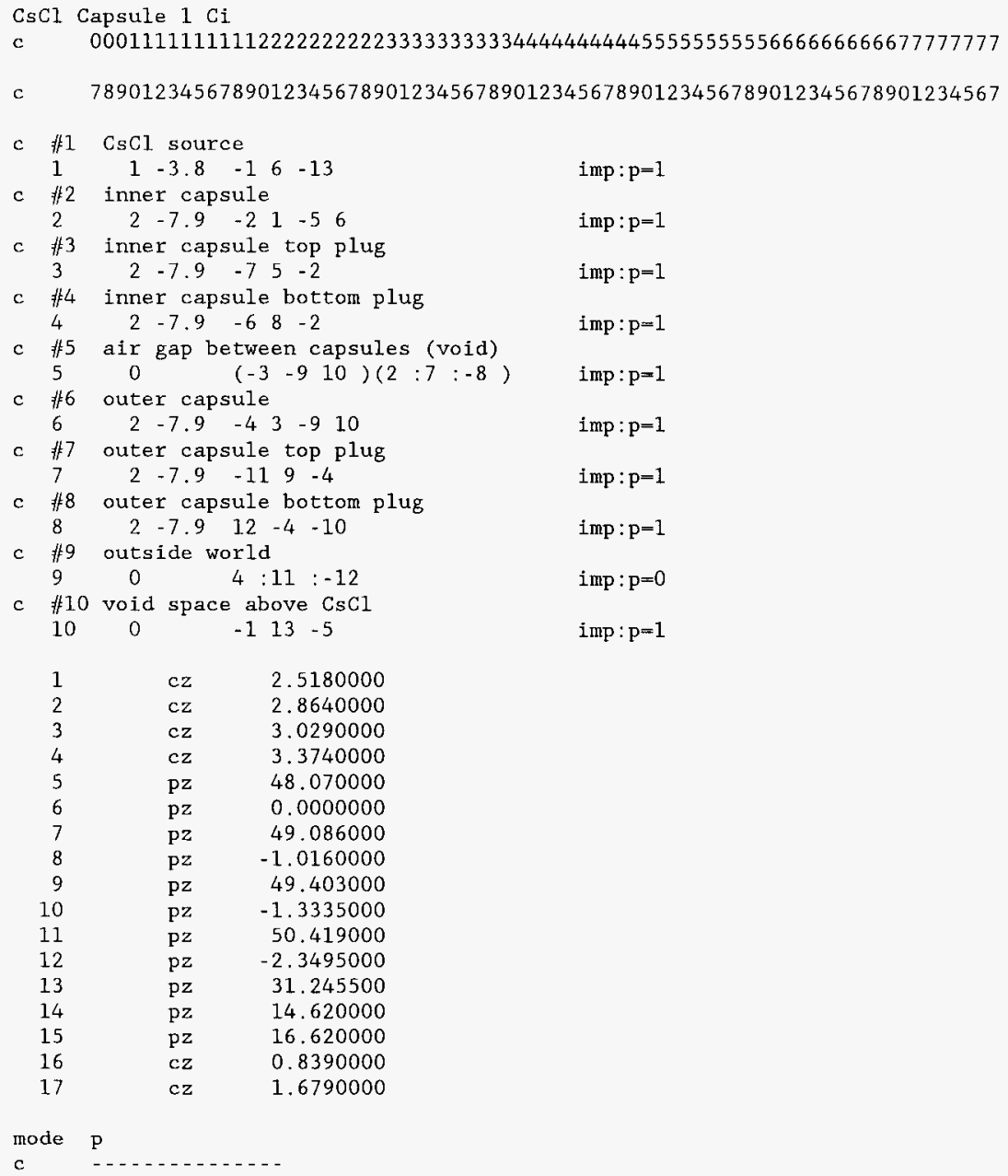




\section{WHC-SD-WM-TI-79I REV 0}

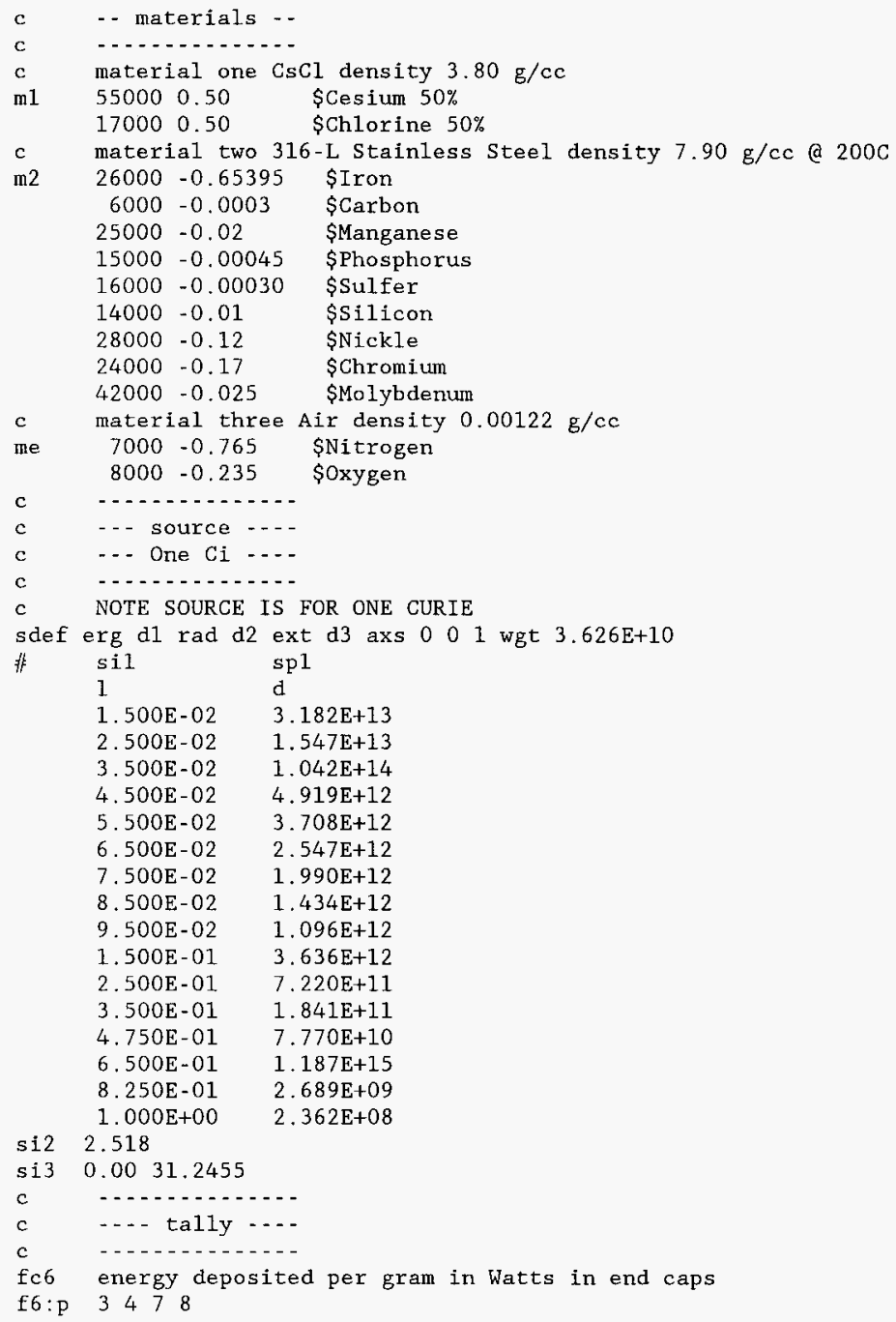




\section{WHC-SD-WM-TI-791 REV 0}

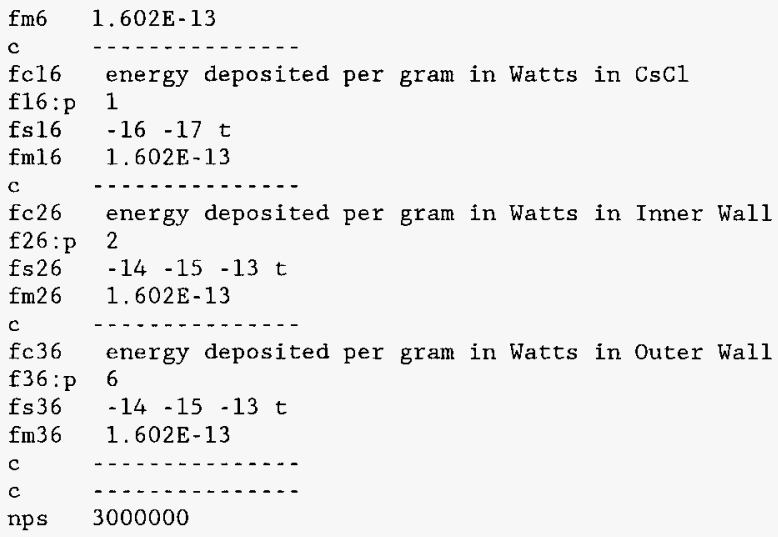




\section{WHC-SD-WM-TI-791 REV 0}

MCNP INPUT FILE FOR 8 CAPSULE OVERPACK - ONE CI PER CAPSULE

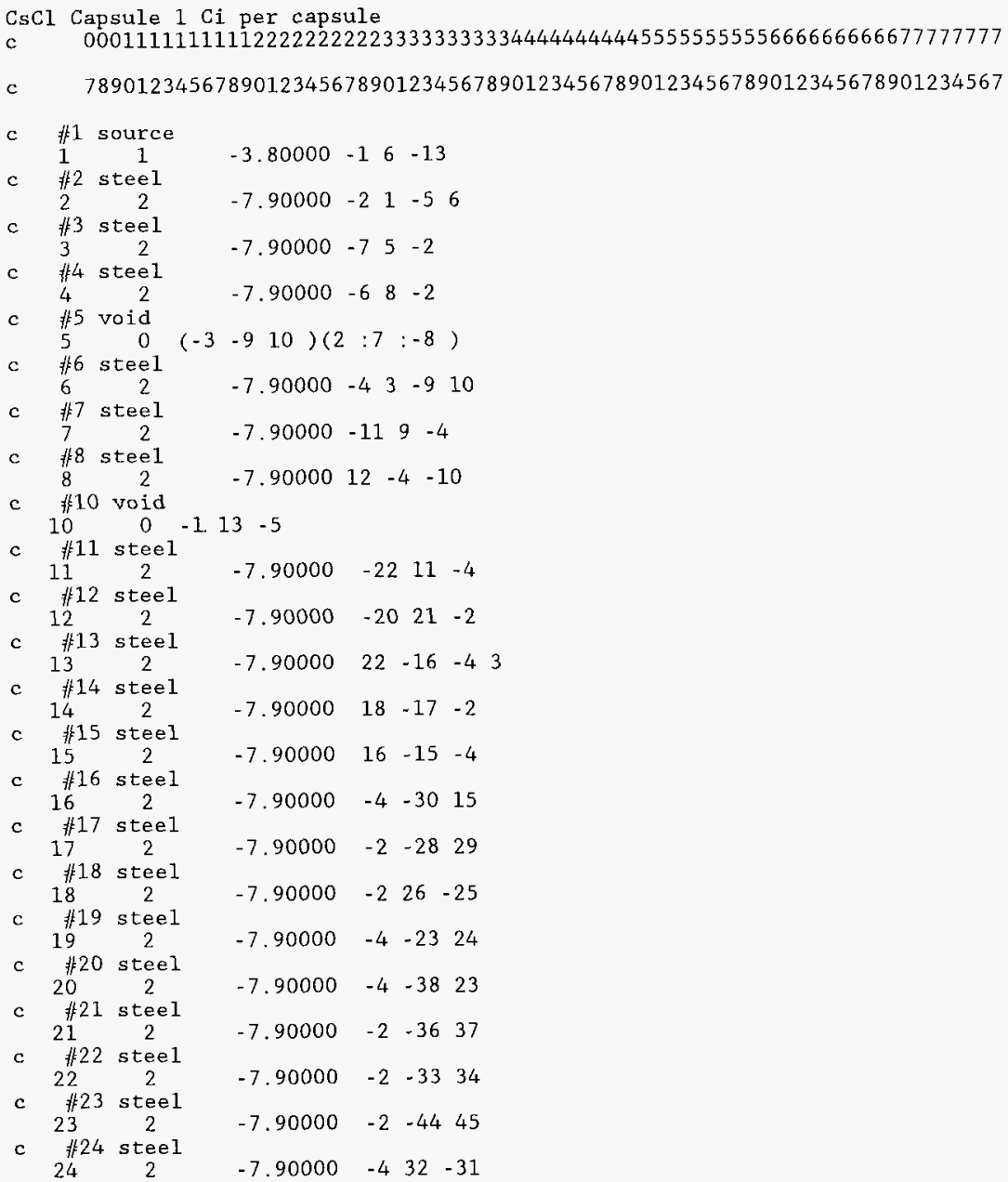




\section{WHC-SD-WM-TI-791 REV 0}

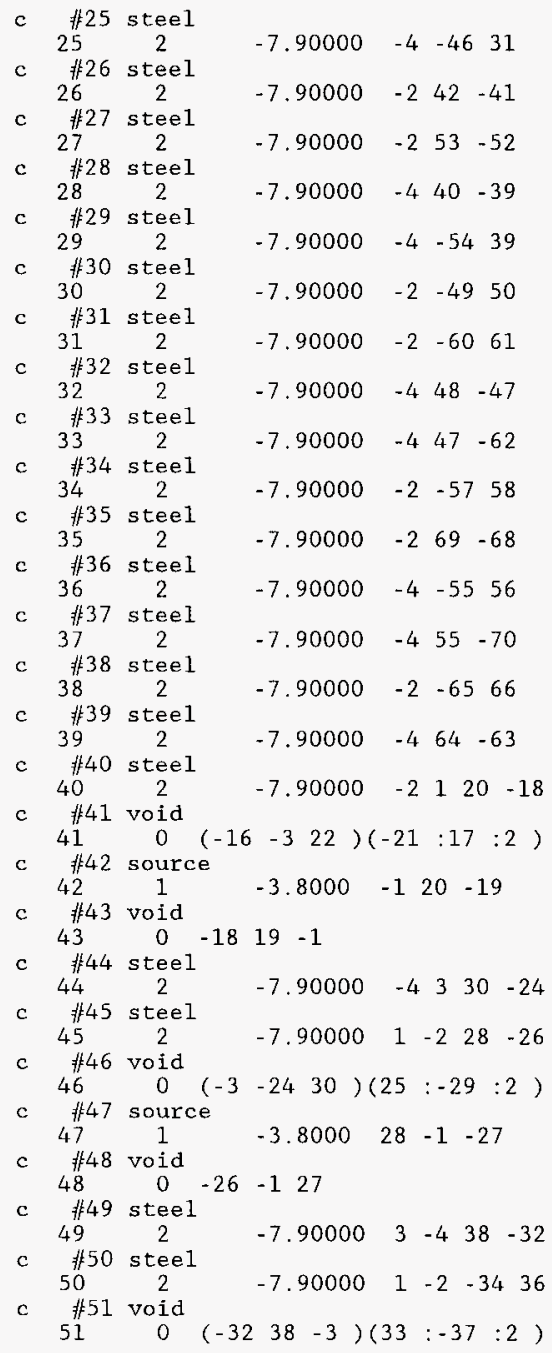




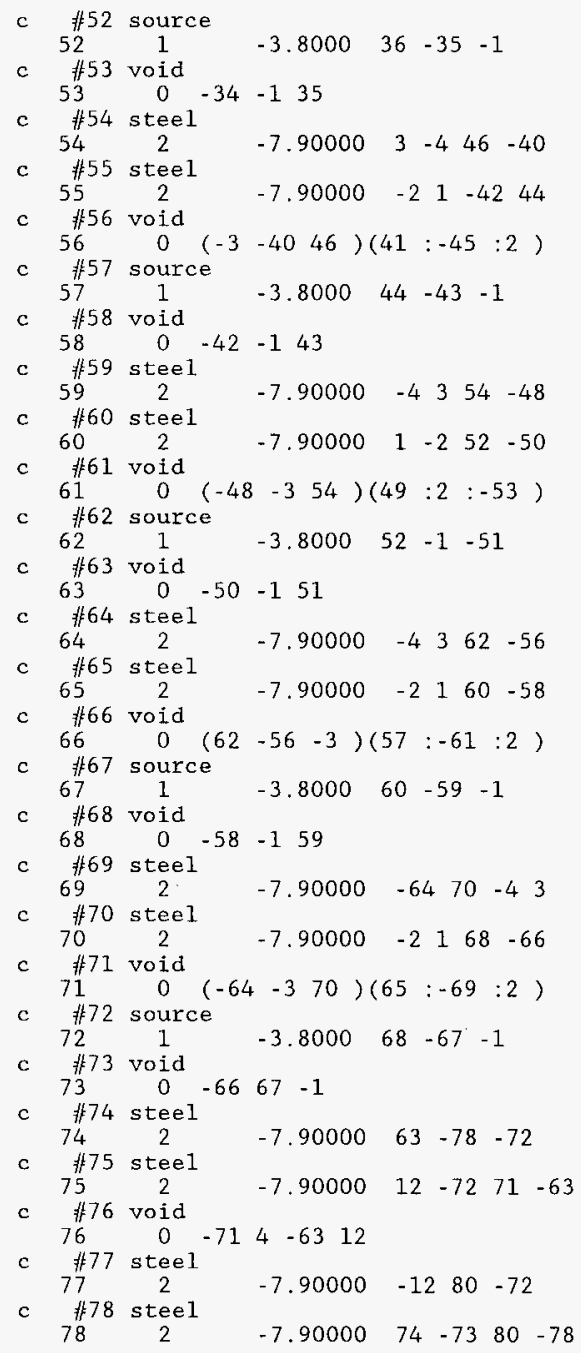




\section{WHC-SD-WM-TI-791 REV 0}

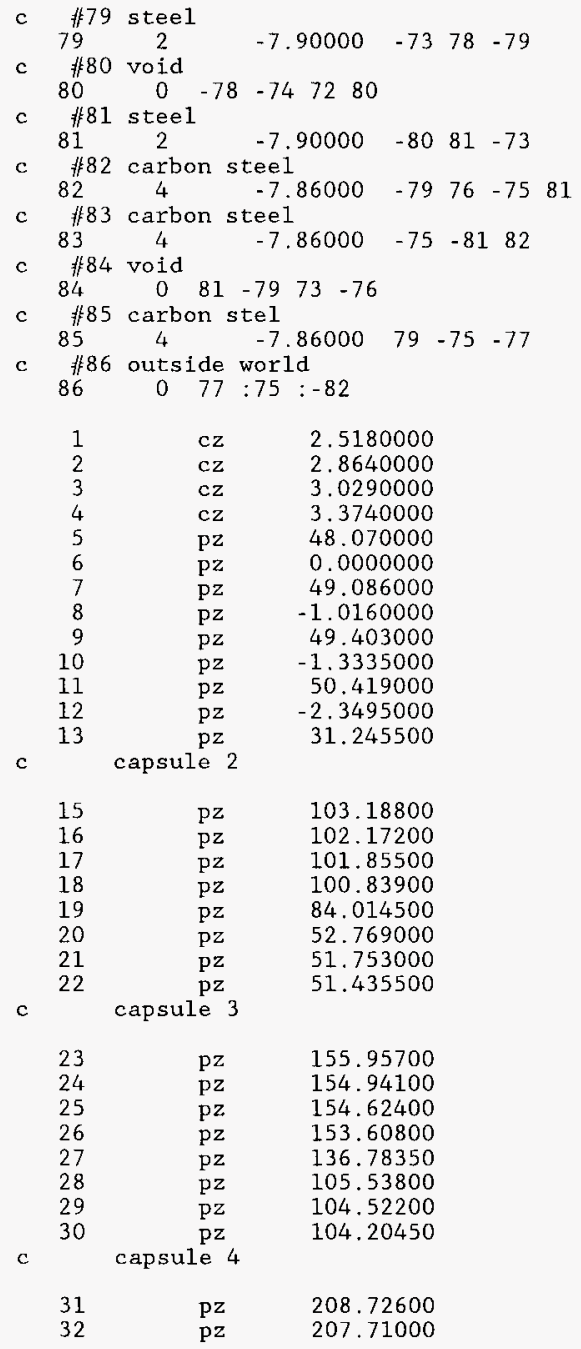




\section{WHC-SD-WM-TI-791 REV 0}

\begin{tabular}{|c|c|c|}
\hline 33 & $\mathrm{pz}$ & 207.39300 \\
\hline 34 & $\mathrm{pz}$ & 206.37700 \\
\hline 35 & $\mathrm{pz}$ & 189.55250 \\
\hline 36 & $\mathrm{pz}$ & 158.30700 \\
\hline 37 & $\mathrm{pz}$ & 157.29100 \\
\hline 38 & $\mathrm{pz}$ & 156.97350 \\
\hline $\mathrm{c}$ & capsule 5 & \\
\hline 39 & $\mathrm{pz}$ & 261.49500 \\
\hline 40 & $\mathrm{pz}$ & 260.47900 \\
\hline 41 & $\mathrm{pz}$ & 260.16200 \\
\hline 42 & $\mathrm{pz}$ & 259.14600 \\
\hline 43 & $\mathrm{pz}$ & 242.32150 \\
\hline 44 & $\mathrm{pz}$ & 211.07600 \\
\hline 45 & $\mathrm{p} z$ & 210.06000 \\
\hline 46 & $\mathrm{pz}$ & 209.74250 \\
\hline c & capsule 6 & \\
\hline 47 & $\mathrm{pz}$ & 314.26400 \\
\hline 48 & $\mathrm{pz}$ & 313.24800 \\
\hline 49 & $\mathrm{pz}$ & 312.93100 \\
\hline 50 & $\mathrm{pz}$ & 311.91500 \\
\hline 51 & $\mathrm{pz}$ & 295.09050 \\
\hline 52 & $\mathrm{pz}$ & 263.84500 \\
\hline 53 & $\mathrm{pz}$ & 262.82900 \\
\hline 54 & $\mathrm{pz}$ & 262.51150 \\
\hline $\mathrm{c}$ & capsule 7 & \\
\hline 55 & $\mathrm{pz}$ & 367.03300 \\
\hline 56 & $\mathrm{pz}$ & 366.01700 \\
\hline 57 & $\mathrm{pz}$ & 365.70000 \\
\hline 58 & $\mathrm{pz}$ & 364.68400 \\
\hline 59 & $\mathrm{pz}$ & 347.85950 \\
\hline 60 & $\mathrm{pz}$ & 316.61400 \\
\hline 61 & $\mathrm{pz}$ & 315.59800 \\
\hline 62 & $\mathrm{pz}$ & 315.28050 \\
\hline$c$ & capsule 8 & \\
\hline 63 & $\mathrm{pz}$ & 419.80200 \\
\hline 64 & $\mathrm{pz}$ & 418.78600 \\
\hline 65 & $\mathrm{pz}$ & 418.46900 \\
\hline 66 & $\mathrm{pz}$ & 417.45300 \\
\hline 67 & $\mathrm{pz}$ & 400.62850 \\
\hline 68 & $\mathrm{pz}$ & 369.38300 \\
\hline 69 & $\mathrm{pz}$ & 368.36700 \\
\hline 70 & $\mathrm{pz}$ & 368.04950 \\
\hline 71 & $c z$ & 3.8100000 \\
\hline 72 & $c z$ & 4.4450000 \\
\hline 73 & $c z$ & 30.480000 \\
\hline 74 & $c z$ & 29.527500 \\
\hline 75 & $\mathrm{cz}$ & 35.560000 \\
\hline 76 & $\mathrm{cz}$ & 34.290000 \\
\hline 77 & $\mathrm{pz}$ & 422.65950 \\
\hline 78 & $\mathrm{pz}$ & 420.43700 \\
\hline
\end{tabular}




\section{WHC-SD-WM-TI-791 REV 0}

$\begin{array}{rll}79 & \mathrm{pz} & 421.38950 \\ 80 & \mathrm{pz} & -2.9845000 \\ 81 & \mathrm{pz} & -3.9370000 \\ 82 & \mathrm{pz} & -5.2070000 \\ 100 & \mathrm{cz} & 0.839 \\ 101 & \mathrm{cz} & 1.679 \\ 102 & \mathrm{pz} & 171.4298 \\ 103 & \mathrm{pz} & 176.4298 \\ 104 & \mathrm{pz} & 224.1988 \\ 105 & \mathrm{pz} & 229.1988\end{array}$

mode $p$

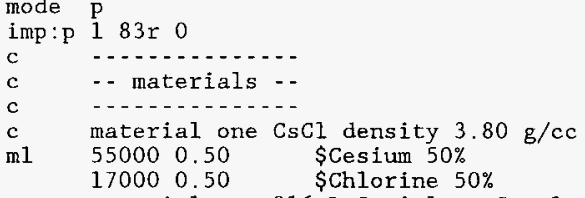

c material two $316-\mathrm{L}$ Stainless Steel density $7.90 \mathrm{~g} / \mathrm{cc}$ a $200 \mathrm{C}$

m2 $26000-0.65395$ SIron

$6000-0.0003$ SGarbon

$25000-0.02 \quad$ \$Manganese

$15000-0.00045 \quad$ \$Phosphorus

$16000-0.00030 \quad$ Sulfer

$14000-0.01 \quad$ SSilicon

$28000-0.12 \quad$ SNickle

$24000-0.17 \quad$ SChromium

$42000-0.025 \quad$ \$Molybdenum

c material three Air density $0.00122 \mathrm{~g} / \mathrm{cc}$

c m3 $\quad 7000-0.765$ \$Nitrogen

c $8000-0.235 \quad$ \$0xygen

c material four Carbon SteeI AISI-SAE 1020 density $7.86 \mathrm{~g} / \mathrm{cc}$

m4 $26000 \quad-0.9926 \quad$ \$Iron

$6000-0.0020 \quad$ \$Carbon

$25000-0.0045 \quad$ \$Manganese

$15000-0.0004 \quad \$$ Phosphorus

$16000-0.0005 \quad \$ S u l f e r$

c $\quad \ldots$ source $\quad \ldots .$.

c $\quad .$. One $\mathrm{Ci} \ldots$

c

c NOTE SOURCE IS FOR ONE CURIE, EIGHT SOURCES!

sdef erg d1 rad d2 ext d3 cel d5 pos fcel d4 axs 001 wgt $2.901 \mathrm{E}+11$

si5 L $1442 \quad 47 \quad 52 \quad 57 \quad 62 \quad 67 \quad 72$

sp5 $\begin{array}{llllllllllll} & 1 & 1 & 1 & 1 & 1 & 1 & 1 & 1\end{array}$

\# sil spl
L
$1.500 \mathrm{E}-02 \quad 3.182 \mathrm{E}+13$
2. $500 \mathrm{E}-02 \quad 1.547 \mathrm{E}+13$
3. $500 \mathrm{E}-02 \quad 1.042 \mathrm{E}+14$
$4.500 \mathrm{E}-02 \quad 4.919 \mathrm{E}+12$
$5.500 \mathrm{E}-02 \quad 3.708 \mathrm{E}+12$
$6.500 \mathrm{E}-02 \quad 2.547 \mathrm{E}+12$ 


\section{WHC-SD-WM-TI-791 REV 0}

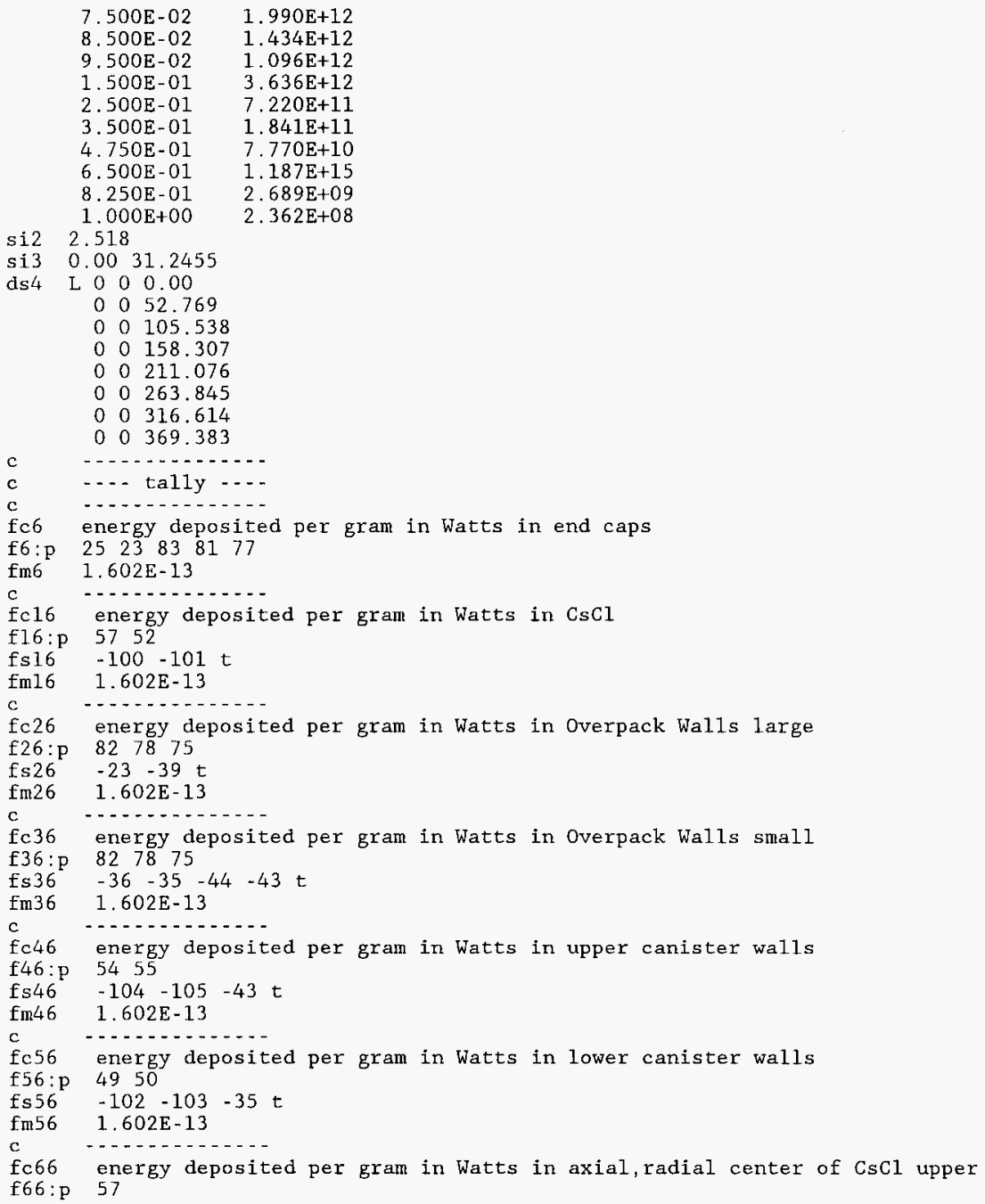




\section{WHC-SD-WM-TI-791 REV 0}

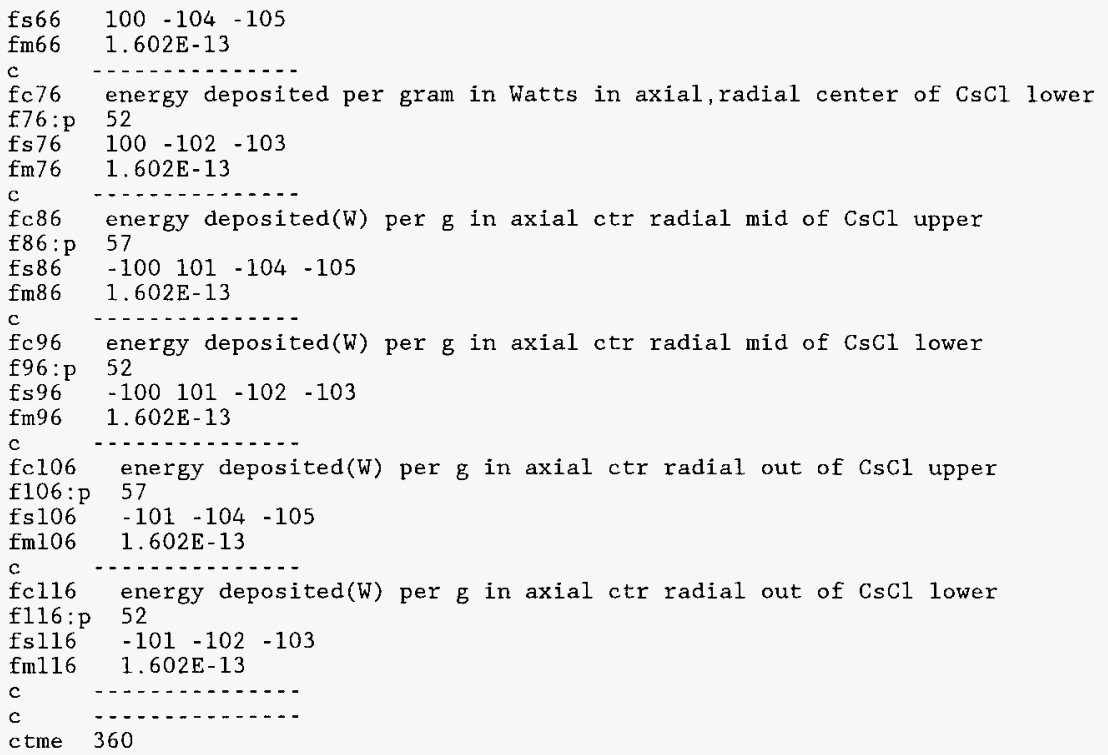


WHC-SD-WM-TI-791 REV 0

\author{
APPENDIX II \\ COPIES OF GUIDANCE LETTERS AND MEMORANDUMS
}


From: $\quad$ Process Technology

$73510-96-028$

Phone: $\quad 376-1456$ H5-27

Date: $\quad$ August 30,1996

Subject: REQUEST FOR RADIATION DECAY ENERGY DEPOSITION ANALYSES TO SUPPORT THERMAL ANALYSES OF HANFORD CESIUM CHLORIDE CAPSULES PER HANFORO PROCESSING FOR TWO DISPOSAL PATH OPTIONS BEING EVALUATED IN A TWRS DECISION ANALYSES

To:

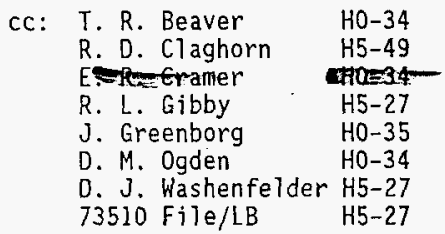

The purpose of this letter is to document the basic scope of the analysis assignment you are to perform. You were identified by your manager (J. Greenborg) as the lead for conducting this analysis assignment, and the following workscope description is in part based on the meeting that Mr. E. R. Cramer, of Process Engineering Analysis, and myself had with you on August 26, 1996 to discuss this matter. Your time charges for this work should be made to the TPCN D5222.

The basic assignment is to provide radiation decay (Cs-137) energy deposition analysis to estimate the specific energy deposition amongst the fabrication components of a capsule and the surrounding components associated with the following design cases:

a) a single capsule surrounded by air;

b) a BUSS cask basket holding 16 capsules (fewer capsules optional) with the basket located in a lag storage pit (high-density concrete lined with stainless steel plate);

c) a set of overpacked capsules surrounded by air, in which a set of 8 capsules are positioned end-to-end along the axial centerline of a right-circular cylinder overpack design (i.e., a stainless steel tube-in-tube overpack configuration where the innermost tube (i.e., holding the capsules) is positioned using four plate-type fins aligned axially along the outer surface of this inner-most tube;

d) two capsule overpacks positioned end-to-end within a given storage tube (vertical orientation) in a Canister Storage Building (CSB) for high-level waste disposal products.

Specific design details to be assumed for component materials, component dimensions, etc., will basically correspond to values for such component designs as used during the radiation dose rate analyses that you did for us during May and June of 1995 in support of an earlier stage of this work. 
A major exception to that information is that the diameter of the capsule overpack design concept has been reduced from 27 inches in diameter (1995 basis) to a value of 24 inches in diameter (1996 basis). During our August 26, 1996 meeting, you indicated that you still had the models for those earlier determinations and that you also had a model for the BUSS cask basket per past work on a safety analysis report for the BUSS cask. Please take advantage of any existing models that are appropriate.

I propose that we handle the remaining parameter value choices by less formal written communication. Such choices, however, should be guided by our interest in establisfing a conservative envelope for such radiation decay deposition (i.e., maximum levels achievable starting from the salt axial centerline, inner capsule wall, outer capsule wall, overpack walls, etc.) for given capsule curie loadings and capsule design, overpack design, etc.. The reason for this is that one of the primary interests relative to the follow-on thermal analysis work is to estimate the maximum salt:metal (inner capsule) interface temperatures that could result from such configurations. We will be looking to your expert technical judgement to help guide us in making those remaining parameter value choices.

Please use the following estimated decayed values for the maximum and average Curie ( $\mathrm{KCi}$ ) loadings per capsule for the $\mathrm{CsCl}$ capsule population as decayed to the calendar years 2010, 2020, and 2035 (Per a disposa? population of 1328 capsules -- WHC/WESF estimates provided to me in FY 1995).

$\begin{array}{ccc}\frac{\text { Year }}{2010} & \frac{\text { Maximum }}{37.65 \mathrm{kC}} & \frac{\text { Average }}{27.77 \mathrm{kCi}} \\ 2020 & \text { (Estimates pending--wil] be provided later) } \\ 2035 & 21.20 \mathrm{kCi} & 15.63 \mathrm{kCi}\end{array}$

The lag storage (BUSS cask basket) case should be analyzed using the estimated values for the maximum and the average capsule inventory for the calendar years 2010 and 2020 . The first priority for a 11 the requested analysis cases is to run the maximum estimated inventory vaiue first. The analysis case involving overpacked capsules placed in a CSB storage tube should be similariy run for the calendar years of 2010, 2020, and 2035, preferably in that sequence.

As I noted during our August 26, 1996 meeting, my review work on the reports of past Monte Carlo analyses of the $[5-137$ decay energy deposition across these Hanford capsules has revealed major differences between such predictions. Please be advised of the need to carefully conduct these analyses so that we can successfully resolve such controversy.

Dr. Gregory Spriggs, of LANL, who did such an analys is (MCNP code), in support of another WHC task during FY 1995, has been reviewing reports that I sent him regarding other such analyses, and he has initiated a new MCNP analysis for a single capsule to help resolve this matter. I will keep you informed on these supporting efforts.

The goal is to try and complete the work in FY 1996. Mr. E. R. Cramer and myself will work with you next week to develop a more detailed and prioritized schedule regarding when you will be able to provide him with the input he will need for his follow-on thermal analysis work. The cost 
R. A. Schwarz

Page 3

August 30,1996

Account Manager (R. D. Claghorn) and myself recognize that in trying to resume such detailed analysis work so late in the fiscal year there will likely be some challenges in trying to complete the work in FY 1996. You indicated during our August 26,1996 meeting that you might have as much as half-time to devote to this effort.

It may be possible to accommodate some workscope carryover into the first quarter of FY 1997 but that is not our preferred plan. Please keep me informed (376-1456) as soon as any potential delays or complications arise.

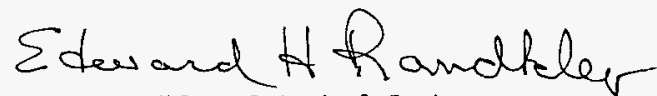

E. H. Randklev, Principal Engineer

Process Technology

ehr 
[475] From: Edward H (Ed) Randklev at WHC133 9/17/96 5:34PM (5661 bytes: 87 ln) To: Randolph A Schwarz at HANFORD07A, Eldon R Cramer at $\sim$ WHC 304

cc: Victor E Roetman at $\sim$ HANFORD07A, Edward H (Ed) Randklev Subject: Informal Notice of Analys is Priorities and Inputs

Randy,

Message Contents

Please do the decay energy deposition work according to the following list, which is arranged in descending priority:

a. single capsule case

b. capsules in an overpack, which is loaded in a Canister Storage Bldg. storage tube.

NOTE: My 8/30/96 letter [73510-96-028] to you was not

explicit enough about this priority. We also

are essentially only interested in the axial midpoint

condition (i.e., worst case), unless the end-effects

thought to be so large that they must be considered.

c. capsules loaded in basket (i.e., the same type as used in a BUSS cask) that is placed in a lag storage

pit.

Eldon and I spoke to Victor Roetman this afternoon, and I realized that I needed to issue some clarification about both the prioritization and the dimensions for some of the cases.

Regarding the dimensions, please use the following:

1. For all analysis cases, use the third generation of wall thicknesses for the inner and outer capsules, respectively. This should be 0.136 inches in wall thickness for both capsules. Inner caps. OUTER dia. is 2.255 ins. (i.e., $21 / 4$ ins. nominal) and the outer caps. had an INNER dia. of $2.385 \mathrm{ins}$, which with the 0.136 in. wall thickness yields alt:54in. 0D (i.e., 2 5/8in. nominal with tolerances). Use the decimal values for finalizing the dimensions. These came from WHC-SD-WM-DIC-004 Rev.0, page 103D by D.F. Washburn, Sr. Hatues seam od but tse-as iste

The capsules are 316 austenitic stainless steel.

2. The overpack should be assumed to be 316 austenitic stainless steel. The outer case of the overpack is nominally $2 \mathrm{ft}$. OD and would be $3 / 8 \mathrm{ins}$. thick. The "guide or positioning tube", which holds the capsules along the axial centerline of the overpack tube, is nominally 3 ins and $1 / 4$ ins thick.

3. The Canister Storage Bldg. will use a steel tube for positioning the overpacks, and this steel tube is to be 28 ins. $O D$ and $1 / 2$ ins. thick. carbon steel. This would leave quite a large radial gap between the overpack $O D$ and CSB tube ID, but for now assume that overpack is held in place to share the same axial centerline. It may turn out that the design will use some form of "sleeve" (steel, etc.) to take up some of space, but for these first analyses do not include any such sleeve. (THIS CSB CASE IS THE MOST IMPORTANT)

4. For the "basket in a

pit", assume that a plate

(same material as the basket) will be 
set on the top of the basket to ensure that the capsules do not protrude above the top of this overall structure (hence will be radially shielded).

5. The basket will set in a stainless steel lined pit (rt. cir. config.). Assume the 316 stainless stee 1 is $1 / 2$ ins. thick and behind it is high-temperature (high density) concrete--very thick.

I think the above information will fill in most of the missing pieces for your current modeling needs, and the prioritization guidance will further help focus the efforts.

I will confirm all this with a WHC internal $1 \mathrm{tr}$. to you for your referencing in preparing the letter report back to me.

I called Gregg Spriggs/LANL today, and he will not get the $U$ of NM MCNP results for a single capsule case for about a month---the fellow is in Europe on business. I will compare your results to Sprigg's reporting (will get you a copy of his report tomorrow) for our initial cross-check. Gregg thought your group's idea of just assuming the beta was all deposited in the salt was fine for this analysis--i.e., conservative relative to my concern for salt/metal interface temperatures and not a significant factor anyway. Gregg still figures that if he did make an error in his MCNP analysis, it will turn out to be that he misinterpreted a piece of the codes output. We can discuss further once we make the comparison---and can call him and also discuss it further as needed.

Later,

Ed R. 
[525] From: Edward H (Ed) Randk]ev at WHC133 9/26/96 5:43PM (1429 bytes: 25 1n)

To: Victor E Roetman at HANF0RD07A, Randolph A Schwarz at HANFORDO7A

ie

cC: Edward $H$ (Ed) Randklev, Eldon R Cramer at WHC304

Subject: EHR Selection of CsCl Density Value and Salt Wt./Caps.

Message Contents

This message is to provide a copy of the values I provided

Victor via our phone discussion about l1AM this morning for use in the MCNP analysis case for the CsCl capsules.

Density of Cesium Chloride ( $\mathrm{CsCl}$ )

Use a value of $3.8 \mathrm{gms} / \mathrm{cc}$

(Eldon and I derived this from values in PNL-5517 that

given for a set of elevated temperatures and which could

be converted to density. The 3.8 value is a value

rounded off from the value attributed to $\mathrm{CsCl}$ at $370 \mathrm{C}$.

In my view this is an appropriately conservative value to use for our MCNP work.)

Weight of $\mathrm{CsCl}$ per capsule:

Use a value of $2.7 \mathrm{~kg}$ of $\mathrm{CsCl}$ per capsule.

(I got this from my draft of a Capsule Description Report Summary)

Let's settle on the strontium fluoride input values

tomorrow.

Later,

Ed R. 


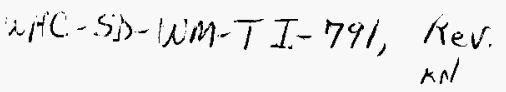

From: Process Technology

73510-96-030

Phone: $\quad 376-1456 \quad H 5-27$

Date: $\quad$ September 30,1996

Subject: REQUEST FOR THERMAL ANALYSES OF HANFORD PROCESSING PER TWO DISPOSAL PATH OPTIONS BEING EVALUATED IN A TWRS DECISION ANALYSIS

To:

\begin{tabular}{|c|c|}
\hline CC: & $\begin{array}{l}\text { D.M. Ogden } \\
\text { D.J. Washenfelder } \\
\text { R.A. Schwarz } \\
\text { V.E. Roetman } \\
\text { R.P. Claghorn }\end{array}$ \\
\hline
\end{tabular}

E. R. Cramer H0-34

Reference: Letter, E. H. Randklev to R. A. Schwarz, "Request for Radiation Decay Energy Deposition Analyses to Support Thermal Analyses of Hanford Cesium Chloride Capsules Per Hanford Processing for Two Disposal Path Options Being Evaluated in a TWRS Decision Analysis," 73510-96-028, dated August 30, 1996.

The purpose of this letter is to formally outline the basic scope of a thermal analysis assignment involving Hanford cesium chloride capsules and strontium fluoride capsules relative to two candidate schemes for Hanford preparations to support final disposal. This information is needed to support a TWRS program decision analysis of Hanford preparation options, preferred disposal path recommendation and then selection of a new TWRS program baseline for capsule disposal.

Most of this information was informally provided to you earlier this month, following your Team Leader (D.M. Ogden) having identified you as the lead for doing this assignment. The circumstances of trying to expedite the restart of FY-96 work on these analyses tasks has necessitated that most of the initial instructions had to be handled informally. Since Mr. T. R. Beaver of your group did similar thermal analyses for us in FY-95 and early FY-96 (i.e., regarding the Hanford capsules of $\mathrm{CsCl}$ and those of $\mathrm{SrF}_{2}$ relative to potential disposal processing situations), we will expect your analyses efforts to utilize Mr. Beaver's models, reference files and technical perspective to the maximum extent practical. Your time for this work should be charged to the TPCN D5222, until the end of FY-96, at which time a new number will be provided.

The basic assignment is to provide us with thermal analyses results and interpretation relative to several proposed design concepts associated with handling and storing these capsules during Hanford preparations for final disposal (off-site) of either the whole capsules or at least their radioisotopic contents. 
Page 2

September 30, 1996

For the analyses cases concerning the Hanford $\mathrm{CsCl}$ capsules, you are to use as input the results of radiation decay (Cs-137, etc.) energy deposition analyses (i.e., Monte Carlo code work) that will be provided by Mr. R. A. Schwarz/WHC and Mr. V. E. Roetman/WHC of the radiation analysis group (Mr. Jess Greenborg/Mgr.). As you know the past thermal analyses cases ( $\mathrm{CsCl}$ capsules), which Mr. Tom Beaver did for us, used radiation decay energy values (i.e., \% of energy deposited) from literature references.

Mr. Beaver's FY-95 analyses used values from RHO-LD-167, Rev.1 by G. D. Campbell/RHO, 1981, and his FY-96 analyses work for us used values from Monte Carlo code work done in the last quarter of FY-95 by Dr. G. A. Spriggs/LANL in support of a Stone and Webster Corp. report on thermal analysis of dry storing the capsules. However, my continued review of the literature has surprisingly revealed even further controversy regarding the estimation of such energy deposition for the $\mathrm{CsCl}$ ( $\mathrm{Cs}-137$ decay) capsules. To resolve this situation, we have recently arranged (Ref.) for WHC radiation analysts to perform Monte Carlo code determinations of these energy deposition values for use as input to your thermal analyses. If time and funding permit, this radiation analysis work will also provide such input values to support your thermal analysis work on cases involving the strontium fluoride capsules.

The requested thermal analyses work involves several different design configurations and additional components other than the capsules. Except for the Hanford capsules, most of the components (e.g., overpack, interim storage tube, lag-storage pit, etc.) are merely design concepts at this time. Hence, I will not be able to give you summary reporting references for configurations, dimensions and material selection and properties. Instead I will provide such detail via several written communications to the analysis teams.

The primary objective for the requested analyses cases is to obtain an estimate of the highest valued radial thermal profile for each set of unique conditions. The analyses cases for the cesium chloride capsules are the first priority, and those for the strontium fluoride capsules are second in priority. The following set of cases are to be done for both the cesium chloride capsules and the strontium fluoride capsules, and the cases outlined in Items a) and b) are considered as precursor analyses cases for the two storage design cases noted in Items $c$ ) and d), with Item $c$ ) being the highest priority overall:

\section{Cesium Chloride Capsules}

a) Do a thermal analysis for a single Hanford CsCl production capsule, in $80^{\circ} \mathrm{F}$ air, for both the maximum and average estimated $\mathrm{kCi} /$ capsule inventories as decayed to calendar year 2000 (i.e., Dec. 31, 2000). Follow this by doing the same analyses for a decay date of 2010. Supplement as appropriate Mr. Beaver's documented technical perspective as to the general parametric response of increasing the air temperature. 


\section{Witc-Sis-WM-TI-791, Rev.}

E. R. Cramer

73510-96-030

Page 3

September 30,1996

b) Do a thermal analysis for a set of overpacked capsules, in $80^{\circ} \mathrm{F}$ air, for the same conditions as noted in Item a) above. The basic overpack design consists of 8 capsules positioned end-to-end along the axial centerline of a metal right-circular cylinder, which is capped at both ends. Assume that the overpack is composed of stainless steel (e.g., 316) that is $3 / 8$ inches thick, 24 inches $0 . D$, and 15 feet long. The capsules will be held in place along the overpack axial centerline by a similar stainless steel guide tube that is nominally 3 inches I.D. and $1 / 4$ inches thick. A small spacer/shock-1imiter disk will separate each capsules. The capsule guide (holder) tube is, for now, assumed to be held in position by four fin-like plates positioned at 90 degrees to the tube surface and 90 degrees between the respective fin plates around the cross-section of the tube.

c) Do a thermal analysis for the case where two overpacks, each containing 8 capsules, are aligned vertically (i.e., end-to-end one over the other) in a steel storage tube of a Canister Storage Building that would be designed for storing such overpacked capsules in preparation for final disposal. Assume that the design for the steel storage tube is the same as currently listed for the vitrified HLW from Phase 1; namely, the each tube will a right-circular cylinder of carbon steel that has an inner diameter of 27 inches and is $1 / 2$ inches thick. Each such storage tube is sealed at the bottom, contains a shock-limiter/overpack holding fixture at the bottom of the first overpack and between the two overpacks and that the top of the tube is sealed with a shielded plug. For now assume that the gap between the outer surface of the overpack and the inner surface of this storage tube is just filled air at atmospheric pressure (i.e., no forced circulation). d) Do a thermal analysis for a lag-storage holding pit that uses the BUSS cask internal basket holding 16 capsules. (NOTE: Depending the results for the 16 capsule design other basket loadings using fewer capsules, e.g., 8 capsules, may be considered for analysis.) The lag-storage pit concept consists of a right-circular cylinder cavity, which would be constructed of thick-walled structural concrete faced with a layer of refractory concrete and then an outer surface layer of stainless steel (e.g., assume it is $3 / 8$ ins. thick) for decontamination control. Assume that the gap between the O.D. of the BUSS cask basket and the I.D. of the pit is nominally 3 inches. Also assume that all gaps (e.g., capsules to BUSS cask basket walls, basket to pit wall, etc.) are filled with air. For the first analysis of this case, assume that there is not a lid over the pit. This assumption will be reviewed after the radiation analysis (R. A. Schwarz/WHC, et.al) work provides some perspective as to the strength of the gamma field coming off the top of such a basket-capsule configuration. Obviously a lid on the lag-storage pit would have significant implications for the thermal conditions of a storage environment. 


$$
u^{\prime} / \bar{C}(-5)-W M-T I-791, \operatorname{Rev}_{\text {KN }} 0
$$

E. R. Cramer

73510-96-030

Page 4

September 30,1996

\section{Strontium Fluoride Capsules}

Do the same set of analyses for the strontium fluoride capsules as detailed in Items a) through d) for the cesium chloride capsules. The BUSS cask basket loading of capsules will be adjusted as needed to match what Hanford has used as the maximum loading per cask for shipping such capsules off-site in the past.

I have already informally provided you with considerable input information, and will formally transmit the key elements of such material for report referencing purposes in the next week or so.

The Cost Account Manager (R. D. Claghorn) and myself recognize that trying to resume such analysis activity so near the end of the fiscal year has presented challenges in trying to get most of the work done during FY-96. What with the uncertainties about FY-97 funding levels and the reassignment of personnel to other contractors, we will no doubt have to do some adjustments of the scope and scheduling to better match the yet to be provided details of the FY-97 funding.

Please keep me informed (376-1456) as to your progress and any potentially significant delays or complications that come up.

\section{Edwerd th Randkler}

Dr. E. H. Randklev, Principal Engineer

Process Technology 
CHECKLIST FOR INDEPENDENT TECHNICAL REVIEW

NUMBER: WHC-SD-TI-791 Rev 0

DOCUMENT REVIEWED

Estimates of Power Deposited Via Cesium Barium Beta and Gamma Radiation Captured in Components of a Hanford Cesium Chloride Capsule and by Components of Overpacked Capsules Places in an Interim Dry Storage Facility

AUTHOR(s) Victor Roetman

I. Method(s) of Review

( $X$ ) Input data checked for accuracy

( ) Independent calculation performed

( ) Hand calculation

( ) Alternate computer code: MICROSHIELD

( ) Comparison to experiment or previous results

() Alternate method (define)

II. Checklist (either check or enter NA if not applied)

( $X$ ) Task completely defined

( $X$ ) Activity consistent with task specification

$(X)$ Necessary assumptions explicitly stated and supported

( $X$ ) Resources properly identified and referenced

$(X)$ Resource documentation appropriate for this application

$(X)$ Input data explicitly stated

$(X)$ Input data verified to be consistent with original source

( $X$ ) Geometric model adequate representation of actual geometry

( $X$ ) Material properties appropriate and reasonable

(NA) Mathematical derivations checked including dimensional consistency

(NA) Hand calculations checked for errors

$(X)$ Assumptions explicitly stated and justified

( $X$ ) Computer software appropriate for task and used within range of validity

(NA) Use of resource outside range of established validity is justified

$(X)$ Software runstreams correct and consistent with results

( $X)$ Software output consistent with input

$(X)$ Results consistent with applicable previous experimental or analytical findings

$(X)$ Results and conclusions address all points and are consistent with task requirements and/or established limits or criteria

$(X)$ Conclusions consistent with analytical results and established 1 imits

(NA) Uncertainty assesment appropriate and reasonable

() Other (define)

III. Comments :

IV. REVIEWER:R. A. Schwarz Ra elems DATE: $12 / 5 / 86$ 


\section{DISTRIBUTION SHEET}

\begin{tabular}{|c|c|c|c|c|c|}
\hline \multirow{2}{*}{$\begin{array}{l}\text { To } \\
\text { Distribution }\end{array}$} & \multirow{2}{*}{\multicolumn{3}{|c|}{$\begin{array}{l}\text { From } \\
\text { Criticality and Shielding }\end{array}$}} & \multicolumn{2}{|l|}{ Page 1 of 1} \\
\hline & & & & \multicolumn{2}{|c|}{$\begin{array}{l}\text { Date } \\
\text { November } 13,1996\end{array}$} \\
\hline \multirow{2}{*}{\multicolumn{4}{|c|}{$\begin{array}{l}\text { Project Title/Work Order } \\
\text { Estimates of Power Deposited Via Cesium/Barium Beta and Gamma } \\
\text { Radiation Captured in Components of a Hanford Cesium Chloride } \\
\text { Capsule and by Components of Overpacked Capsules Placed in an } \\
\text { Interim Dry Storage Facility }\end{array}$}} & \multicolumn{2}{|c|}{ EDT No. 619220} \\
\hline & & & & \multicolumn{2}{|l|}{ ECN No. } \\
\hline Name & MSIN & $\begin{array}{l}\text { Text } \\
\text { With All } \\
\text { Attach. }\end{array}$ & Text Only & $\begin{array}{l}\text { Attach.f } \\
\text { Appendix } \\
\text { Only }\end{array}$ & $\begin{array}{l}\text { EDT/ECN } \\
\text { Only }\end{array}$ \\
\hline R. D. Claghorn & \multicolumn{3}{|l|}{ H5-49 } & & \\
\hline E. R. Cramer & \multicolumn{3}{|l|}{$\mathrm{HO}-34$} & & \\
\hline J. Greenborg & \multicolumn{3}{|l|}{ HO-35 } & & \\
\hline E. H. Randk $1 \mathrm{ev}$ & \multicolumn{3}{|l|}{ H5-27 } & & \\
\hline V. E. Roetman & \multicolumn{3}{|l|}{ HO-35 } & & \\
\hline R. A. Schwarz & \multicolumn{3}{|l|}{$K 8-34$} & & \\
\hline Central Files $(1+$ Original) & \multicolumn{3}{|l|}{ A3-88 } & & \\
\hline
\end{tabular}

